\title{
Kénorganikus kémiai kutatások az ELTE Szerves Kémiai Tanszékén, 1953-2012. Témavezető: Dr. Kucsman Árpád professzor
}

\author{
RUFF Ferenc, JALSOVSZKY István, RÁBAI József, SZABÓ Dénes*
}

ELTE Szerves Kémiai Tanszék, Pázmány Péter sétány 1/A, 1117 Budapest, Magyarország

Kucsman Árpád 1927-ben született Budapesten. Személyiségét és tudományos pályafutását döntő mértékben befolyásolták a fasori gimnáziumban (1937-1945) és az Eötvös Kollégiumban (1945-1950) eltöltött évei. Egyetemi tanulmányait az Eötvös Loránd Tudományegyetemen végezte (1945-1949). Diplomájának megszerzése után az ELTE Szerves Kémiai Tanszékére került. Kezdetben Müller Sándor professzor munkatársa volt a propenil-oldalláncú fenoléterek dimerizációjával kapcsolatos témában. Szerkesztőként azonban hamarosan bekapcsolódott Bruckner Győző professzor Szerves Kémia tankönyvének megírásába. A tankönyvírással kapcsolatosan felmerült probléma keltette fel érdeklődését a kénorganikus kémia iránt, és 1953-tól ez a téma vált fő kutatási területévé. Tudományos pályája egyenes ívben folytatódott. 1959-ben doktorált és adjunktusi kinevezést kapott, 1965-ben megszerezte a kémiai tudomány kandidátusa címet és kinevezték egyetemi docenssé, 1972-ben megvédte akadémiai doktori értekezését, és egyetemi tanárrá nevezték ki. 1971-ben a nyugdíjba vonuló Bruckner Győző professzor után Kucsman Árpád lett a Szerves Kémiai Tanszék vezetője. Ezt a funkciót 1993-ig töltötte be. 1997-ben nyugdíjba vonult,

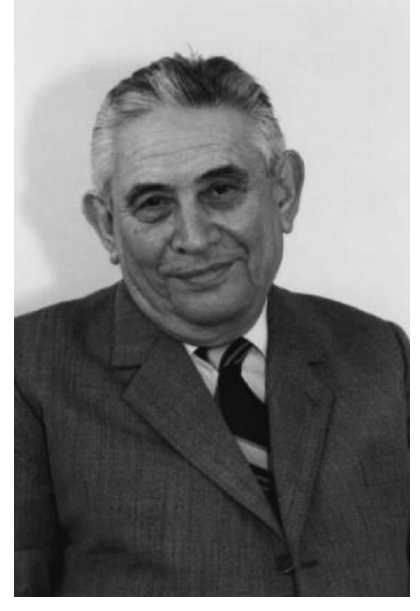
1998-ban professzor emeritus címet kapott, 2007-ben az Eötvös Loránd Tudományegyetemen honoris causa professzori címmel tüntették ki. Érdeklődése a tanszéki oktatási problémák és kénkémiai kutatások iránt, a későbbi években gyengülő egészségi állapota ellenére, 2012-ben bekövetkezett haláláig töretlenül megmaradt. A Kucsman Árpád professzor által vezetett kutatócsoport kénorganikus kémia terén elért tudományos eredményeit, témák szerint csoportosítva, a következők szerint foglalhatjuk össze.

\section{Szulfiliminek szerkezete}

A kénorganikus kémiai kutatások egy kötéselméleti problémából indultak ki. Az RR'SX típusú kénvegyületek nem planáris, királis szerkezete alapján általánosan elfogadottá vált az a nézet, hogy az $S$ és $X$ atomok közötti kötés dipoláris $\left(\mathrm{S}^{+}-\mathrm{X}^{-}\right)$jellegü. Kucsman professzor 1953-ban megjelent dolgozatában $^{1}$ viszont kifejtette, hogy a háromligandumos kénvegyületek piramisos szerkezete a kénatom $d$ és az $\mathrm{X}$ atom $p$ pályája közötti kettős kötés $(\mathrm{S}=\mathrm{X})$ kialakulása mellett is értelmezhető. Stabilis RR'SX típusú vegyületek sorába tartoznak pl. a szulfoxidok (RR'S=O) és a szulfiliminek (RR'S=NQ; Q = $\mathrm{ArSO}_{2}, \mathrm{COCHCl}_{2}$ ). Kötéselméleti kutatások céljára különösen az utóbbi vegyületcsoport mutatkozott alkalmasnak. Ha ugyanis a kén- és nitrogénatomok közötti kettős kötés körüli rotáció gátolt, akkor a szulfilimineknél egyrészt cisz-transz izoméria $(\mathbf{1 , 2})$, a kénhez kapcsolódó azonos R=R' csoportokkal szubsztituált gauche konformációjú származékoknál pedig királis szerkezetek $(\mathbf{3 , 4})$ kialakulásával lehet számolni (1.ábra.)

Mivel a klasszikus preparativ kémiai módszerek alkalmazása a sztereoizomerek szétválasztása és kimutatása terén nem vezetett eredményre, ${ }^{2-8}$ a csoport figyelme a szulfiliminek kötésrendszerének felderítésére az IR, UV és NMR spektroszkópia, valamint a röntgendiffrakció és a kvantumkémia felé fordult. A szulfiliminek IR spektrumában ${ }^{9-11,16,36}$ az SN kötés vegyértékrezgéséhez rendelhető sávok frekvenciája [RR'SNSO ${ }_{2} \mathrm{Ar}: v(\mathrm{SNS})=950 \mathrm{~cm}^{-1}, \mathrm{RR}^{\prime} \mathrm{SNCOCHCl}_{2}$ : $v(S N)=800 \mathrm{~cm}^{-1}$ ] arra utal, hogy a kén és a nitrogén atomok között $d \pi-p \pi$ kötés alakul ki. Ez a kötés azonban a kötésfrekvenciák összehasonlítása alapján szulfoxidok analóg kötésénél polárisabb [RR'SO: $i(\mathrm{SO})=1050 \mathrm{~cm}^{-1}$ ].

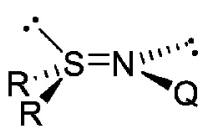

3<smiles></smiles>

4

1. Ábra. A szulfiliminek lehetséges szerkezete.

\footnotetext{
*Tel.: +361372 2500; e-mail: szabod@elte.hu
} 


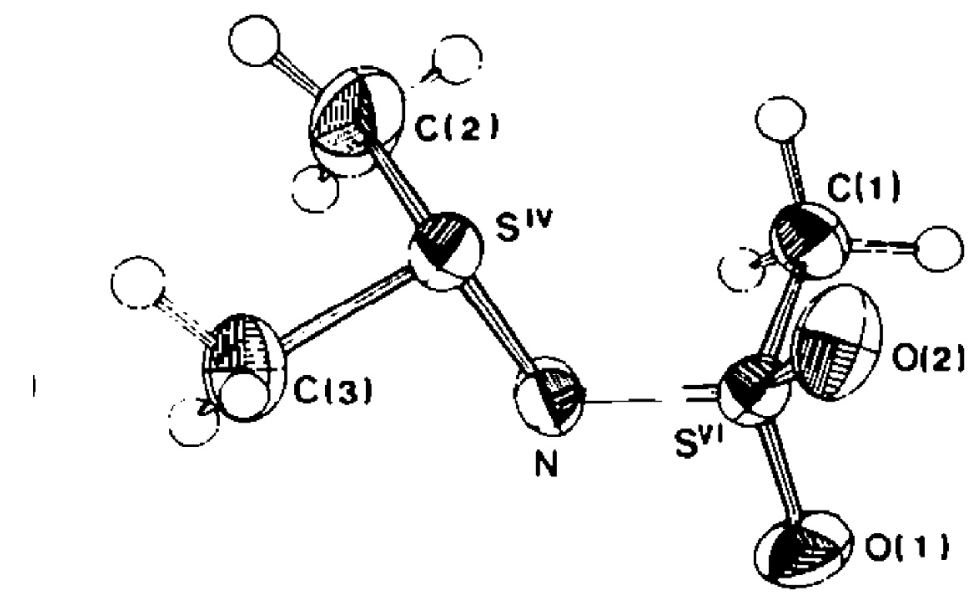

2. Ábra. Az S,S-dimetil-N-mezil-szulfilimin rötgendiffrakciós szerkezete.

A $\mathrm{Me}_{2} \mathrm{SNSO}_{2} \mathrm{Me}$ szulfilimin UV spektrumában ${ }^{12}$ a kén magános elektronpárjának $n \rightarrow \pi *$ átmenetéhez tartozó sáv 200 nm-nél kisebb hullámhossznál található, a dimetil-szulfoxid analóg abszorpciója viszont 220 nm-nél van. A szulfilimineknél a kénatom magános elektronpárjának gerjesztése tehát nagyobb energiát igényel, mint a szulfoxidoknál, ami a szulfiliminek kénatomjának nagyobb pozitív töltésével és $d \pi-p \pi$ kötésük nagyobb polaritásával függ össze.

Röntgendiffrakciós mérések ${ }^{14,15,23,25,30,32,50,54}$ is igazolták, hogy a szulfiliminekben az $\mathrm{S}^{\mathrm{IV}} \mathrm{NS}^{\mathrm{VI}}$ és az $\mathrm{S}^{\mathrm{IV}} \mathrm{NC}=\mathrm{O}$ atomokon delokalizált $\pi$-kötésrendszer alakul ki. A kötéshosszak alapján $\left[\mathrm{Me}_{2} \mathrm{SNSO}_{2} \mathrm{Me}: R\left(\mathrm{~S}^{\mathrm{IV}} \mathrm{N}\right)=1.63 \AA, R\left(\mathrm{~S}^{\mathrm{VI}} \mathrm{N}\right)=1.58 \AA ;\right.$ $\mathrm{Me}_{2} \mathrm{SNCOCHCl}_{2}: R\left(\mathrm{~S}^{\mathrm{IV}} \mathrm{N}\right)=1.67 \AA$ ] , az SN kötések egyszeres kötésnél erősebbek. Kristályokban a molekuláknak királis gauche konformációja van jelen (2. ábra).

$\mathrm{Az} \mathrm{S}^{\mathrm{IV}} \mathrm{N} d \pi-p \pi$ kötés azonban ezt a konformációt nem rögzíti. NMR vizsgálatok ${ }^{18}$ szerint oldatban a $\mathrm{Me}_{2} \mathrm{SNSO}_{2} \mathrm{Me}$ szulfilimin $\mathrm{S}^{\mathrm{IV}}$ atomhoz kötődő metilcsoportjai ekvivalensek. Az $\mathrm{S}^{\mathrm{IV}} \mathrm{N}$ atomok közötti $d \pi-p \pi$ kapcsolat tehát a kötés körüli rotációt nem gátolja. Kvantumkémiai számítások ${ }^{22,26,29,34,40,45,52}$ szintén alátámasztották, hogy az $\mathrm{N}$-szulfonil szulfiliminek $\mathrm{S}^{\mathrm{IV}} \mathrm{N}$ és $\mathrm{S}^{\mathrm{VI}} \mathrm{N}$ kötése az egyszeres kötésnél erősebb, a kristályrácsban megjelenő gauche konformer az egyik energiaminimumnak felel meg. A különböző konformerek közötti energiagátak viszont olyan alacsonyak, hogy oldatban az egyes konformerek rotációval szinte szabadon egymásba alakulhatnak. A $d \pi-p \pi$ kötés kialakulásakor a nitrogén $p$ pályája a kén öt $d$ pályája közül bármelyikkel átfedésbe kerülhet, és ez a rotáció energiagátjának csökkenését eredményezi. Az N-szulfonilszulfiliminek esetében az $\mathrm{S}^{\mathrm{IV}} \mathrm{N}$ és $\mathrm{S}^{\mathrm{VI}} \mathrm{N}$ kötések $\pi$-kötésrendje szinte független a kén-nitrogén kötések körüli elfordulás szögétől, és a konjugáció kiterjedésével csökken.

\section{A szulfiliminek képződésének mechanizmusa}

A szulfiliminek szulfidok és N-klórsavamidok reakciójában állíthatók elö. ${ }^{2,3} \mathrm{Az} \quad \mathrm{N}$-szulfonil-szulfiliminek esetében $\mathrm{N}$-klórszulfonamidokat (pl. klóramin- $\mathrm{T}, p-\mathrm{MeC}_{6} \mathrm{H}_{4} \mathrm{SO}_{2} \mathrm{NCINa}$, TsNCINa), az N-acetil típusú vegyületeknél karbonsavamidot és nátrium-hipokloritot használunk a vegyületek előállítására. A reakcióban a szulfiliminek mellett, a szulfid szerkezetétől és a reakció körülményeitől függően változó hozammal szulfoxidok is keletkeznek (3. ábra).

$$
\begin{gathered}
\text { RR'S }+ \text { TsNCINa } \rightarrow \text { RR'SNTs }+\mathrm{NaCl} \\
\text { RR'S }+ \text { TsNCINa }+\mathrm{H}_{2} \mathrm{O} \rightarrow \mathrm{RR}^{\prime} \mathrm{SO}+\mathrm{TsNH}_{2}+ \\
\mathrm{NaCl} \\
\text { RR'S }+\mathrm{NaOCl}+\mathrm{CHCl}_{2} \mathrm{CONH}_{2} \rightarrow \\
\text { RR'SNCOCHCl}+\mathrm{NaCl}_{2}+\mathrm{H}_{2} \mathrm{O} \\
\text { RR'S }+\mathrm{NaOCl} \rightarrow \text { RR'SO }+\mathrm{NaCl}
\end{gathered}
$$

3. Ábra. A szulfidok és N-klórsavamidok vizet tartalmazó közegben lejátszódó reakciói.

A szulfidok és N-klórszulfonamidok közötti reakciók mechanizmusának felderítésére reakciókinetikai vizsgálatokat végeztünk. ${ }^{19,20,35,38,55}$ Megállapítottuk, hogy a reakciók sebesség-meghatározó lépésében a pozitív klór elektrofil addíciója révén klórszulfónium kation $\left(\mathrm{RR}^{\prime} \mathrm{SCl}^{+}\right)$és szulfonamidát anion $\left(\mathrm{TsNH}^{-}\right)$ionpárt alkotó intermedierek képződnek (4. ábra). Klórozószerként az N-klórszulfonamidok (TsNHCl) és a diszproporciónálódási reakciójukban kialakuló $\mathrm{N}, \mathrm{N}$-diklórszulfonamidok $\left(\mathrm{TsNCl}_{2}\right)$ szerepelnek. A szulfilimin végtermék a szulfonamidát anion klórszulfónium kationon végrehajtott nukleofil szubsztitúciójában, a szulfoxid pedig a klórszulfónium kation hidrolízisénél keletkezik. 


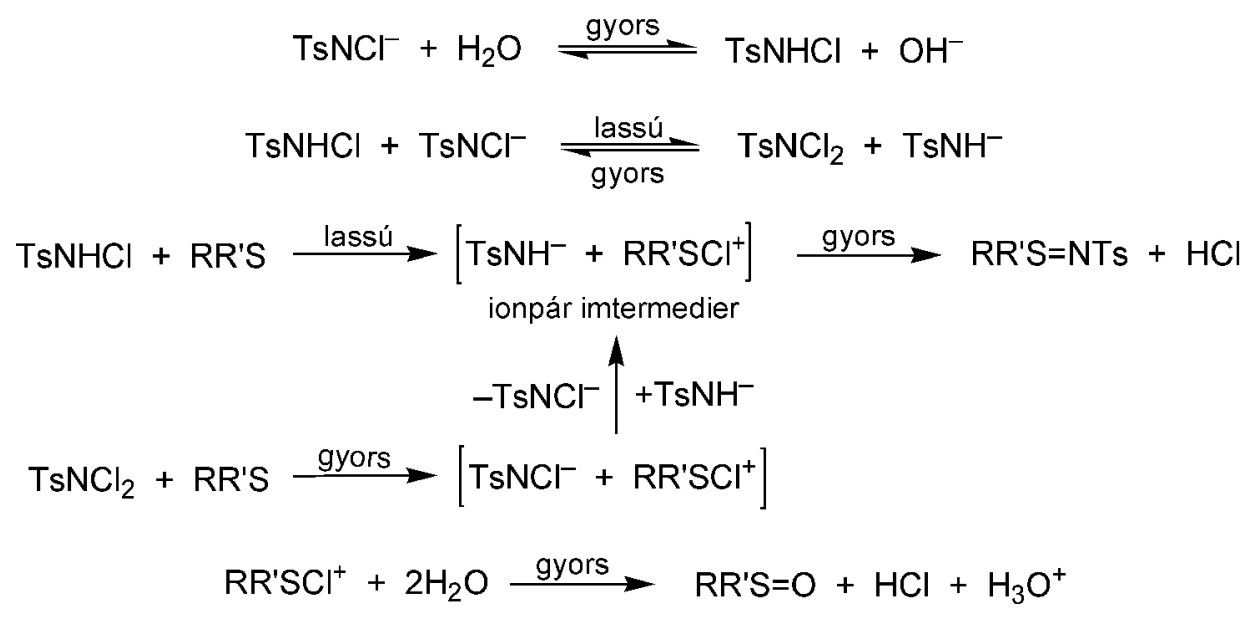

4. Ábra. A szulfidok és klóramin-T reakciójának mechanizmusa.

A klór elektrofil addíciójával lejátszódó reakciólépésben (5. ábra, 5 $\rightarrow$ 6) elektrosztatikus stabilizáción és $n-\sigma^{*}$ jellegü delokalizáción alapuló, új típusú szomszédcsoport közremúködést észleltünk. ${ }^{42,70}$ A szulfidok aromás gyürüjéhez kapcsolódó orto helyzetű karbonilcsoportok az oxigénatom negatív polározottságának nagyságától függő mértékben növelik a reakció sebességét. Szomszédcsoport közremüködés a termékekhez vezető nukleofil szubsztitúciós reakciólépésben is fellép. Az orto-karboxi-fenil szulfidok reakciójában, vizet akár csak nyomokban is tartalmazó közegben, aciloxi-szulfónium kation intermedieren keresztül csak szulfoxidok keletkeznek $(6 \rightarrow 7 \rightarrow 8)$.

A klórszulfónium kation intermedier rendkívül kicsi stabilitása és rövid élettartama miatt a szulfilimin és szulfoxid termékek keletkezésének sztereokémiáját ${ }^{49}$ az aszimmetrikus indukció jelenségének felhasználásával vizsgáltuk (6. ábra). Királis $\alpha$-szénatomot tartalmazó szulfidból [ $\left.\left(\mathrm{R}_{\mathrm{C}}\right)-9\right]$ kiindulva két, klórszulfónium kation és szulfonamidát anion ionpárt tartalmazó intermedier diasztereomer keletkezik $\quad\left[\left(\mathrm{R}_{\mathrm{C}} \mathrm{R}_{\mathrm{S}}\right)-\mathbf{1 0}, \quad\left(\mathrm{R}_{\mathrm{C}} \mathrm{S}_{\mathrm{S}}\right)-\mathbf{1 0}\right]$, amelyekből a $\mathrm{TsNH}^{-}$és a víz nukleofil támadásával alakulnak ki a termékek két-két diasztereomerjeinek keverékei. (A 6. ábrán csak a nagyobb mennyiségben keletkezett diasztereomereket ábrázoltuk.) A reakcióelegyek HPLC analízisével ${ }^{51}$ megállapítottuk, hogy a termékek nagyobb mennyiségben keletkező diasztereomerjei [( $\left.\mathrm{R}_{\mathrm{C}} \mathrm{R}_{\mathrm{S}}\right)$-12, $\left.\left(\mathrm{R}_{\mathrm{C}} \mathrm{S}_{\mathrm{S}}\right)-14\right]$ a kénatomon heterokirálisak. Az eredményt azzal magyaráztuk, hogy a szulfilimin a klórszulfónium kation-szulfonamidát anion ionpárból retencióval, a szulfoxid viszont a külső nukleofil vízzel inverzióval keletkezik. Ha viszont a hipokloritot $\left(\mathrm{Cl}^{+}\right)$és a tozilamidátot egymást követö külön lépésekben adjuk a szulfidhoz, akkor a nagyobb mennyisében keletkező szulfilimin és szulfoxid diasztereomerek a kénatomon azonos konfigurációjúak $\left[\left(\mathrm{R}_{\mathrm{C}} \mathrm{S}_{\mathrm{S}}\right) \mathbf{- 1 0} \rightarrow\left(\mathbf{R}_{\mathrm{C}} \mathrm{S}_{\mathrm{S}}\right) \mathbf{- 1 2}+\right.$ $\left(\mathrm{R}_{\mathrm{C}} \mathrm{S}_{\mathrm{S}}\right)$-14)], homokirálisak, mert azonos sztereokémiájú hátoldali támadásban alakulnak ki.<smiles></smiles>

5<smiles>[X]c1oc(C)c2ccccc12</smiles>

6<smiles>C[As]1OC(=O)c2ccccc21</smiles>

7<smiles>C[C@H](O)c1cccc(S(C)=O)c1C(=O)O</smiles>

8

5. Ábra. Szomszédcsoport közreműködés szulfidok és klóramin-T reakciójában.

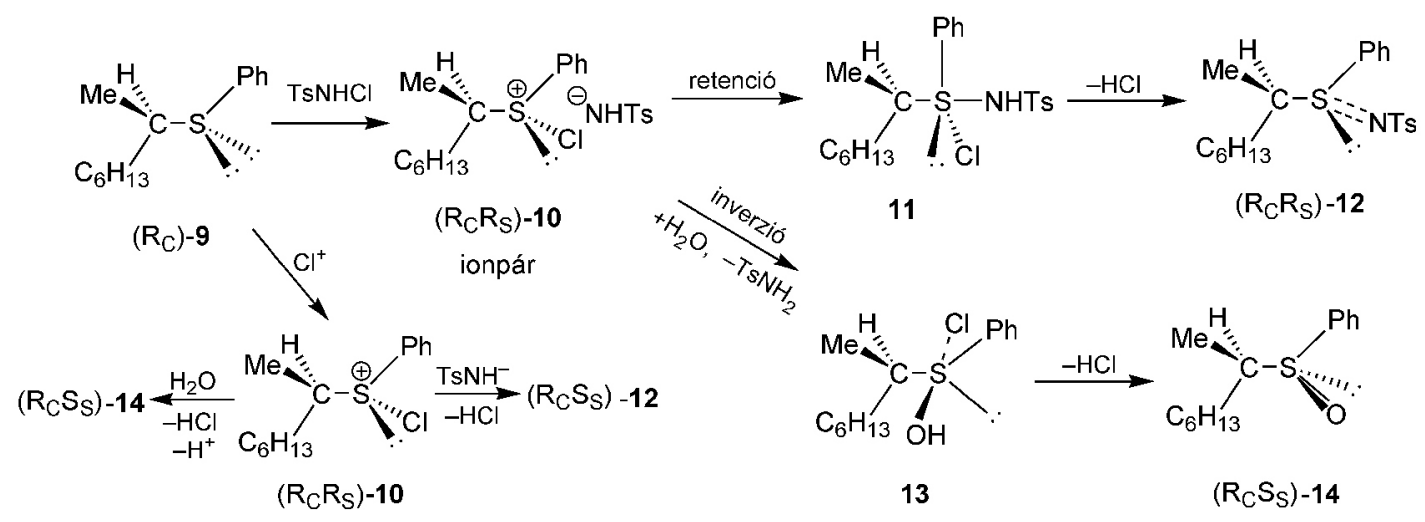

6. Ábra. Aszimmetriás indukció királis szulfidok és klóramin-T reakciójában. 


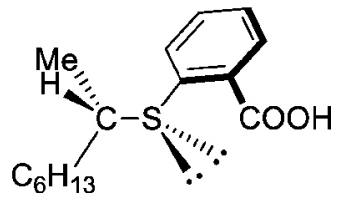

$\left(\mathrm{S}_{\mathrm{C}}\right)-15$<smiles>CCCCCC[C@H](C)S(=O)(=O)c1ccccc1C(=O)O</smiles>

$\left(\mathrm{S}_{\mathrm{C}} \mathrm{R}_{\mathrm{S}}\right)-19$

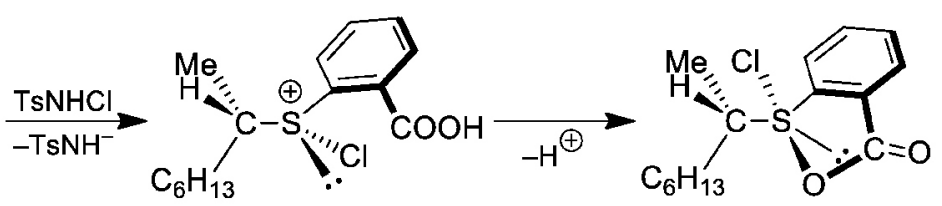

$\left(S_{C} R_{S}\right)-16$

7. Ábra. Szomszédcsoport közremüködés királis szulfidok és klóramin-T reakciójában.

Királis $\alpha$-szénatomot és orto-karboxi-fenil csoportot tartalmazó szulfidok $\quad\left[\left(\mathrm{S}_{\mathrm{C}}\right)-15\right] \quad$ szomszédcsoport közremüködéssel lejátszódó reakciójában a termékek a kénatomot tekintve homokirálisak $\left[\left(\mathrm{S}_{\mathrm{C}} \mathrm{R}_{\mathrm{S}}\right)\right.$-19 és $\left(\mathrm{S}_{\mathrm{C}} \mathrm{R}_{\mathrm{S}}\right)$-20, 7. ábra]. A szomszédos karboxilcsoport nukleofil támadása a klórszulfónium kation kénatomján megelözi a TsNH ${ }^{-}$és a víz támadását. Mindkét termék az aciloxiszulfónium kation intermedierből [ $\left(\mathrm{S}_{\mathrm{C}} \mathrm{R}_{\mathrm{S}}\right)$-18] inverzióval keletkezik.

\section{Gyürüs szulfilimin és szulfoxid diasztereoizomerek előállítása és szerkezete}

Az aszimmetrikus indukció alkalmazásával végzett kísérletek tapasztalatait felhasználva megvizsgáltuk miként befolyásolja az öttagú gyürüs tiolánok és a hattagú gyürüs tiánok $\alpha$-szénatomjához kapcsolódó alkilcsoport a kialakuló cisz és transz szulfilimin és szulfoxid izomerek arányát ${ }^{63,64,82}$ (8. ábra). A 2-alkil-tiánokat (21b) klóramin-T-vel reagáltatva (B módszer) főleg transz-szulfilimineket (23) kapunk, a 2-alkil-tiolánok (21a) esetében viszont a cisz és transz izomerek $(\mathbf{2 4}, \mathbf{2 5}) \mathrm{kb}$. azonos arányú keveréke keletkezik. Ha viszont a klórozás első lépését $t$-butil-hipoklorittal végezzük, majd ezután adjuk hozzá a tozilamidátot (A módszer), akkor a tiánoknál és tiolánoknál egyaránt cisz-szulfiliminek (22) képződnek.
A tiánokat és tiolánokat metanolban $t$-butil-hipoklorittal, -78 ${ }^{\circ} \mathrm{C}$-on klórozva, majd nátrium-karbonátot adva a reakcióelegyhez (C módszer) nagyobb mennyiségben cisz-szulfoxidok (26) keletkeznek. Tiánokat kloroformban reagáltatva $t$-butil-hipoklorittal és vízzel hidrolizálva a reakcióelegyet (D módszer) jó termeléssel transz-szulfoxidok (27) nyerhetők. Tiolánokból krómtrioxidos oxidációval (E módszer) állíthatók elö a transz-szulfoxidok (28).

A gyürüs szulfoxidok keletkezésének mechanizmusát a 2-alkil-tiolánok és 2-alkil-tiánok $t$-butil-hipoklorittal lejátszódó reakciójában tanulmányoztuk ${ }^{92}$ (9. ábra). A reakciókban klórszulfónium kation (30) intermedieren keresztül reverzibilisen metoxiszulfónium sók (32) képződnek, melyek kloridion jelenlétében diklórszulfánon (31) keresztül ekvilibrálódhatnak. A metoxicsere sebessége az öt- és hattagú gyürüs vegyületeknél egyaránt a transz származékoknál gyorsabb. Az egyensúly így a ciszmetoxiszulfónium sók irányába tolódik el, ezek termodinamikailag stabilisabbak, kitermelésük nagyobb. A szulfoxidok a kloridionnak a $\mathrm{CH}_{3} \mathrm{O}$ csoport szénatomján végbemenő nukleofil támadásában $(\mathbf{3 2} \rightarrow \mathbf{3 3})$ alakulnak ki.

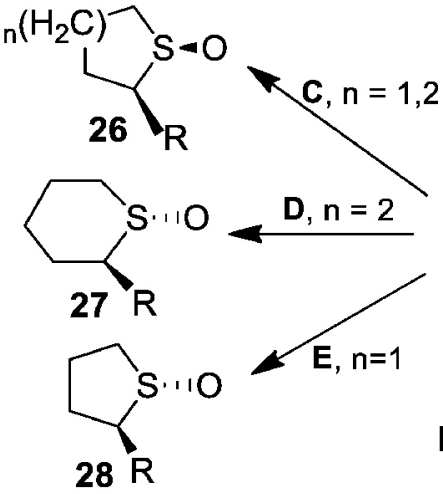

$28 \mathrm{R}$

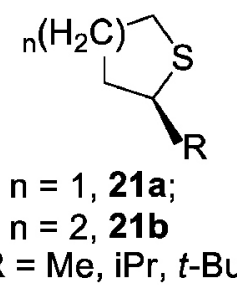

$\mathrm{R}=\mathrm{Me}, \mathrm{iPr}, t-\mathrm{Bu}$
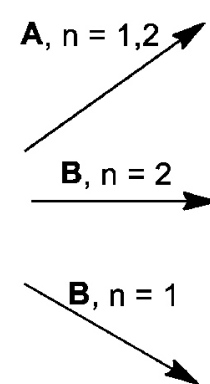<smiles></smiles>

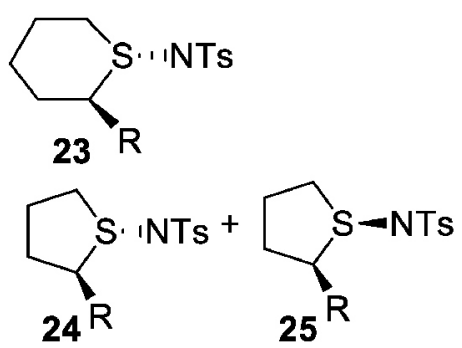

Módszerek: A: $t$-BuOCl, $\mathrm{MeOH},-78^{\circ} \mathrm{C}$, TsNH $2_{2}-\mathrm{TEA}, \mathrm{DMFA}-\mathrm{MeOH}$; $\mathrm{B}: \mathrm{TsNCINa}, \mathrm{MeOH}, 20^{\circ} \mathrm{C}$; C: $t$-BuOCl, $\mathrm{MeOH}, \mathrm{Na}_{2} \mathrm{CO}_{3},-78^{\circ} \mathrm{C}$, D: $t$-BuOCl, $\mathrm{CHCl}_{3},-50^{\circ} \mathrm{C}, \mathrm{H} 2 \mathrm{O}, 0^{\circ} \mathrm{C} ; \mathrm{E}: \mathrm{CrO}_{3}$, piridin, $0^{\circ} \mathrm{C}$

8. Ábra. Gyürüs szulfiliminek és szulfoxidok sztereoszelektiv szintézise. 


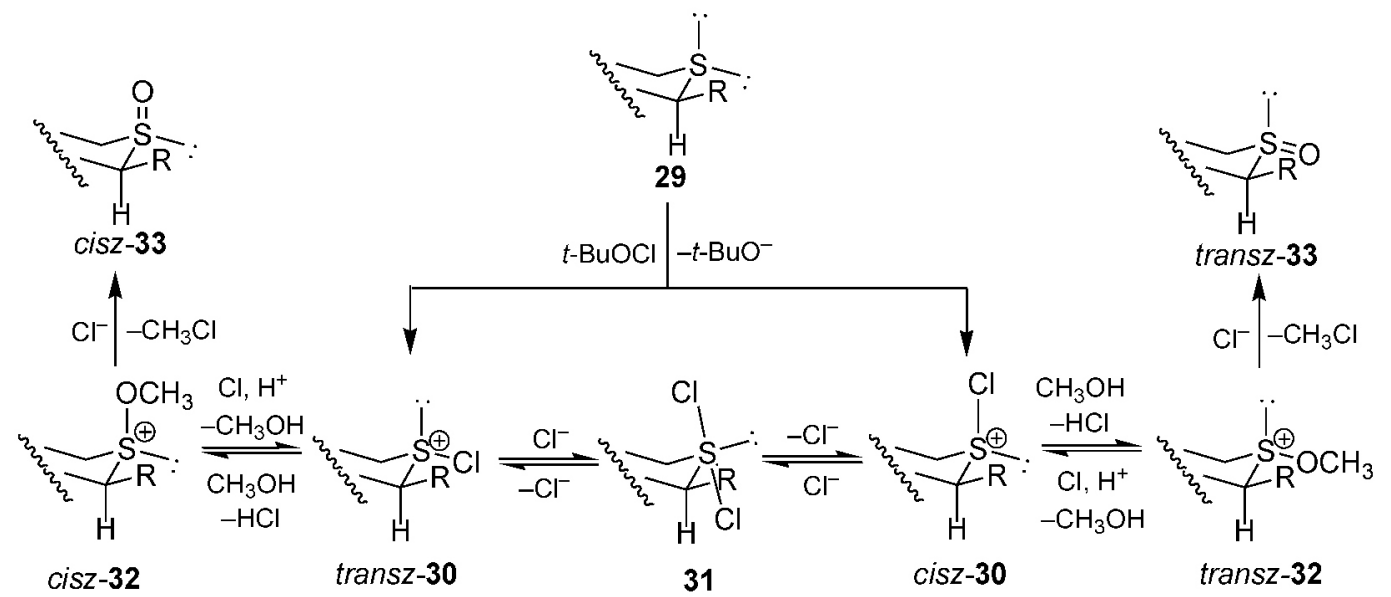

9. Ábra. A kloridion katalitikus hatása gyürüs szulfoxidok keletkezésében.

Röntgendiffrakciós vizsgálatokkal ${ }^{65,66}$ meghatároztuk a tiánés tiolán-1-tozilimid valamint cisz- és transz-2-alkil származékaik konformációját (10. ábra). Az elektronvonzó tozilimino csoport axiális helyzetet foglal el a tián-1-tozilimidben (34) valamint a cisz-2-alkil-tián-1tozilimidek (35) esetében. Ekvatoriális térhelyzetü viszont a tozilimino csoport a transz származékoknál (36). A 2-alkilcsoportok minden izomernél ekvatoriálisak. A tián gyürű torzult szék konformációjú. A 2-szubsztituált-tián1-tozilimidek (35, 36) konformációját a szin-axiális kölcsönhatás és a sztérikus taszítás határozza meg. A tozilimino csoport a tiolán-1-tozilimidben (37) pszeudoaxiális. Az 1,2-diszubsztituált-tiolánok esetében a cisz származékoknál (38) a tozilimino csoport axiális, az alkilcsoport ekvatoriális. A transz származékoknál (39) a tozilimino csoport 1-endo-izoklinális, az alkilcsoport 2-exo-izoklinális. Az $\mathrm{S}^{\mathrm{IV}} \mathrm{N}, \mathrm{N}-\mathrm{S}^{\mathrm{VI}}$ és $\mathrm{S}^{\mathrm{VI}} \mathrm{C}_{\mathrm{Ar}}$ kötések körüli rotációt a szterikus effektusokkal, a konjugációval és az $n-\sigma^{*}$ típusú sztereoelektronos effektusokkal lehet magyarázni.

\section{Szulfónium centrumon lejátszódó nukleofil szubsztitució. A szulfiliminek hidrolízise}

A háromligandumos kénatomon lejátszódó nukleofil szubsztitúciók mechanizmusát a szulfiliminek savas hidrolízisén tanulmányoztuk kinetikai módszerekkel. ${ }^{27,37} \mathrm{~A}$ reakció savkatalizált, a szubsztrát protonálódásával kezdődik. A szulfiliminek a nagyon gyenge bázisok körébe tartoznak, UV fotometriás módszerrel meghatározott $\mathrm{pK}_{\mathrm{a}}$ értékük -1,8 és -3,0 közé esik. ${ }^{28} \mathrm{~A}$ reakció további lépései a kénatomhoz kapcsolódó szubsztituensektől függenek. Amennyiben csak a szulfonamido csoport lehet a távozócsoport, akkor a reakció a víz $\mathrm{S}^{\mathrm{IV}}$ atomon lejátszódó nukleofil addíciójával folytatódik. Az $\mathrm{S}^{\mathrm{IV}}-\mathrm{N}$ kötés hasadását és a szulfoxid keletkezését az oldószer segítségével létrejövő protonátmenetek segítik elő (11. ábra).

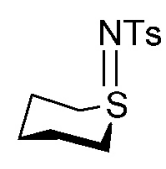

34

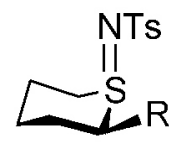

35

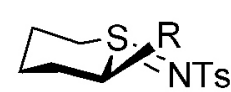

36<smiles>[N-]=S=C1CC1</smiles>

37

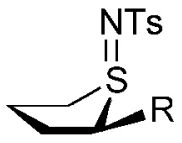

38

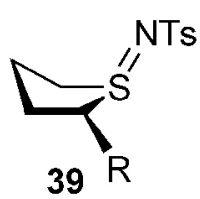

$39 \mathrm{R}$

10. Ábra. Gyürüs szulfiliminek konformációja.
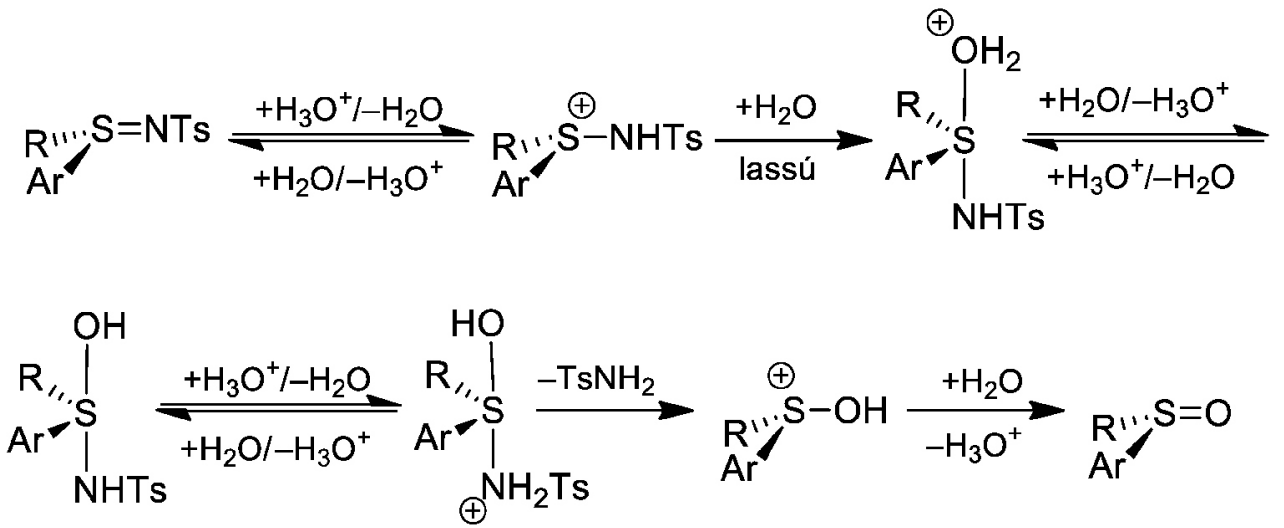

11. Ábra. Szulfiliminek savas hidrolízisének $\mathrm{S}_{\mathrm{N}} 2$ mechanizmusa. 


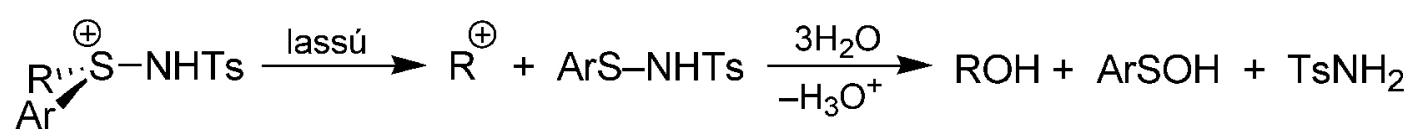

\section{$\mathrm{ArSOH} \rightarrow \mathrm{ArSSAr}+\mathrm{ArSSO}_{2} \mathrm{Ar}$}

12. Ábra. Szulfiliminek savas hidrolízisének $S_{\mathrm{N}} 1$ mechanizmusa.

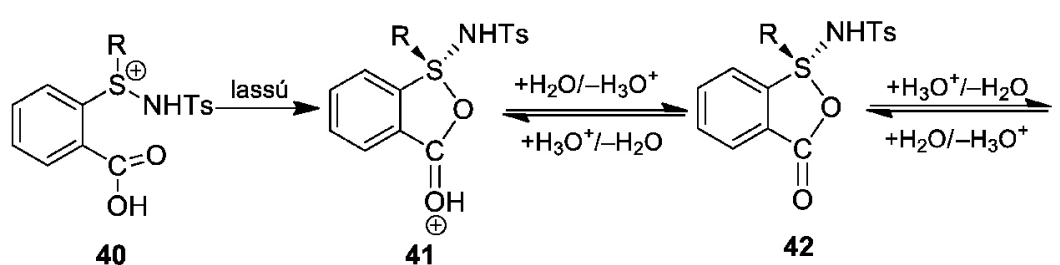

40

41

42

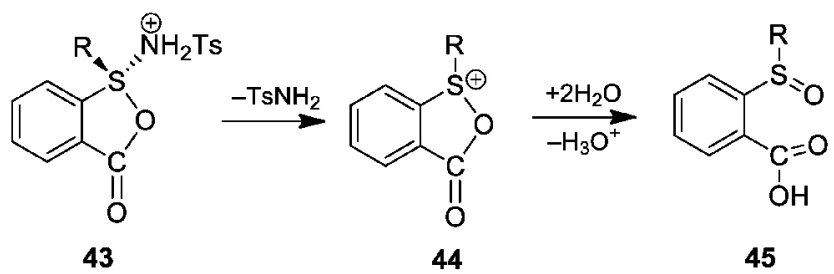

13. Ábra. Szulfiliminek szomszédcsoport közreműködéssel lejátszódó savas hidrolízise.

Ha a kénatom egyik szubsztituense karbokation képzésére hajlamos, akkor unimolekuláris reakcióban az $\mathrm{S}^{\mathrm{IV}}$-C kötés hasad el, végtermékként pedig diszulfidok és tiolszulfonátok keletkeznek $^{37}$ (12. ábra).

A fenil gyürün orto helyzetben karboxilcsoportot tartalmazó szulfilimineknél (40), szomszédcsoport közremüködés révén a reakció sebessége jelentősen megnő, aciloxi-szulfán (42) és aciloxi-szulfónium só (44) intermediereken keresztül keletkezik a szulfoxid (45) végtermék ${ }^{37}$ (13. ábra).

\section{Szulfoxidok képződése szulfidok oxidációs reakcióiban}

Régóta ismert, hogy a szulfidok nátrium-perjodáttal enyhe körülmények között szulfoxiddá oxidálhatók. A reakció mechanizmusát kinetikai módszerekkel vizsgáltuk. ${ }^{59}$ Megállapítottuk, hogy a bimolekuláris reakciót az elektronküldő csoportok $(\rho=-1.4)$, az oldószer polaritásának és kisebb mértékben az ionerősségnek a növekedése gyorsítja. Deutérium oldószer-izotópeffektus az átalakulás során nem lép fel. A szulfidok reakciópartnere a perjodát anion, amelynek hidratált formái viszont semleges vagy gyengén savas közegben, lényegesen kisebb reakciókészségük miatt számottevően nem vesznek részt az átalakulásban. A reakció korai átmeneti állapotban megvalósuló egylépéses elektrofil oxigén transzfer a perjodát iontól a szulfid kénatomja felée ${ }^{59,125}$ (14. ábra).<smiles>[R6][R6]O[Sb]</smiles>

14. Ábra. A szulfidok perjodátos oxidációjának mechanizmusa.

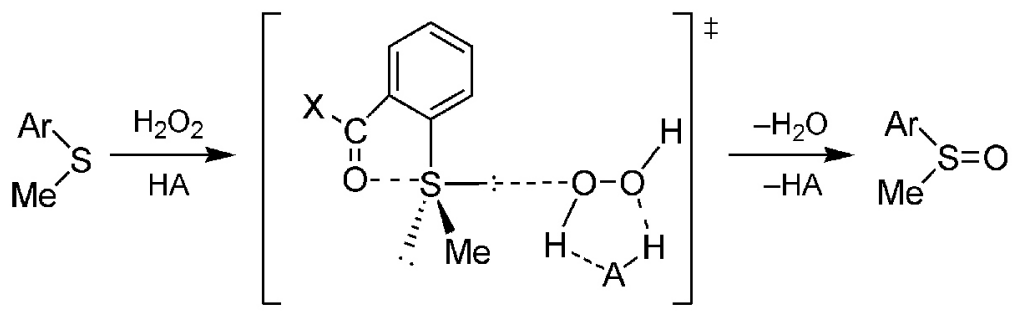

15. Ábra. Szomszédcsoport közreműködés szulfidok peroxidos oxidációjában.<smiles>[R][R]S[R]</smiles>

16. Ábra. Szulfidok oxidációja fenil-trimetilammónium-tribromiddal. 
A szulfidok perjodátos és az ugyancsak egylépéses oxigén transzfer reakcióval lejátszódó peroxidos oxidációjában kisebb mértékü szomszédcsoport közremüködést észleltünk. ${ }^{70,80} \mathrm{~A}$ poláris átmeneti állapotot a közelben elhelyezkedő poláris szubsztituensek stabilizálják (15. ábra), vonzó S•••O nemkötő kölcsönhatás kialakításával növelik a reakció sebességét $\left(\mathrm{CH}_{2} \mathrm{OH}<\mathrm{CH}_{2} \mathrm{CO}_{2} \mathrm{H}<<\mathrm{CH}_{2} \mathrm{CO}_{2}^{-}<\mathrm{CO}_{2} \mathrm{H}<\mathrm{CONH}_{2}<<\right.$ $\mathrm{CO}_{2}^{-}$). A szomszédcsoport közremúködés nagyságát az elektronos és szterikus effektusok leválasztásával, orto és para szubsztituált aril-metil-szulfidok reaktivitásának összehasonlításával értékeltük. ${ }^{70}$

Különböző szulfidok (dialkil-, alkil-aril, benzil- és szubsztituált-diaril) szelektíven és jó termeléssel oxidálhatók a megfelelö szulfoxidokká fenil-trimetilammónium- tribromid (PTAB) felhasználásával vizes piridines oldatban. Ez a módszer lehetőséget ad ${ }^{18} \mathrm{O}$ jelzett szulfoxidok előállítására is a felhasznált $\mathrm{H}_{2}{ }^{18} \mathrm{O}$ izotóparányának megtartásával ${ }^{81}$ (16. ábra).

\section{6. $\lambda^{4}$-Szulfánok felfedezése}

A négyértékü, négy-ligandumos kénatomot tartalmazó kénvegyületeket, a $\lambda^{4}$-szulfánokat (korábbi nevén a szulfuránokat) reakciókban fellépő intermedierként szinte már a kénkémiai kutatások kezdete óta feltételezték, ilyen típusú szerves vegyületet elöállítani azonban 1971-ig senkinek sem sikerült. Ebben az évben publikálta Kapovits István $^{24}$ a vegyületcsoport első spirociklusos (46), J. C. Martin és munkatársai ${ }^{127,128}$ pedig az aciklusos (47) képviselöjét. A spirociklusos vegyületek lényegesen stabilisabbak és sokkal könnyebben kinyerhetők, mint a szobahőmérsékleten és levegőn rendkívül gyorsan elbomló aciklusos származékok.

A $\lambda^{4}$-szulfánokban a kénatom vegyértékei trigonális bipiramisos (TBP) orientációt mutatnak. Ekvatoriális helyzetben, egy síkban az aromás gyürük és a magános elektronpár, a síkra merőlegesen apikális helyzetben pedig az eletronegatívabb heteroatomok, pl. oxigén vagy nitrogénatomot tartalmazó szubsztituensek helyezkednek el. ${ }^{61,127,128}$ A spiro- $\lambda^{4}$-szulfánok királis szerkezetűek, azonos ekvatoriális és apikális csoportokat tartalmazó származékaik is enantiomer párként vannak jelen (46).<smiles>C[Sn]1(I)OC(=O)C(=O)c2ccccc21</smiles>

$(S)-(+)-46$<smiles>C[Si]1(C)OC(=O)c2ccccc2[C@H]1c1ccccc1</smiles>

$(\mathrm{R})-(-)-46$<smiles></smiles>

47
17. Ábra. Az elsőként publikált $\lambda^{4}$-szulfánok

\section{Spiro- $\lambda$ 4-szulfánok előállítása}

A diarilbisz(aciloxi)spiro- $\lambda^{4}$-szulfánt (46) Kapovits ${ }^{24}$ bisz(2-karboxiaril)-szulfidból (48) vízmentes dioxánban klóramin-T-vel (QCl = TsNCINa) állította elő (18. ábra). Az eljárást más halogénezőszerekre $\left(\mathrm{TsNCl}_{2}, t-\mathrm{BuOCl}, \mathrm{Cl}_{2}\right.$, $\left.\mathrm{NBS}, \mathrm{PhI}(\mathrm{OAc})_{2}\right)$ és oldószerre $(\mathrm{AcOH}$, piridin) is kiterjesztették, ${ }^{46}$ de a szulfidok anódos oxidációjával ${ }^{33}$ is megoldották. Korábbi kutatások alapján ${ }^{35,42}$ a reakciókban intermedierként először klórszulfónium kation (49), majd a karboxilcsoport gyürüzárásával (aciloxi)(klór)- $\lambda^{4}$-szulfán (50) keletkezik, amely a kloridion disszociációja és a második gyürüzárás után alakul át a végtermékké (18. ábra).

A spiro- $\lambda^{4}$-szulfánok (46) bisz(2-karboxiaril)szulfoxidokból (51) is előállíthatók ${ }^{47}$ (19. ábra) acilező szerekkel (AcCl, $\mathrm{Ac}_{2} \mathrm{O} / \mathrm{AcOH}$, dioxán, piridin), vagy vízelvonással (DCC/dioxán, hevítés $240^{\circ} \mathrm{C}$-on difilben).

A spiro- $\lambda^{4}$-szulfánok (46) vízzel szulfoxidokká (52) hidrolizálnak, amelyeknek ${ }^{18} \mathrm{O}$ izotóp tartalma a reakcióban használt vízével azonos (19. ábra). Hevítés hatására az ${ }^{18} \mathrm{O}$ atommal jelölt szulfoxidból (52) csak ${ }^{18} \mathrm{O}$ izotópot nem tartalmazó spiro- $\lambda^{4}$-szulfán (46) keletkezik. ${ }^{47}{ }^{18} \mathrm{O}$ izotóppal jelölt szulfoxidokból (52) kiindulva, a $\lambda^{4}$-szulfán

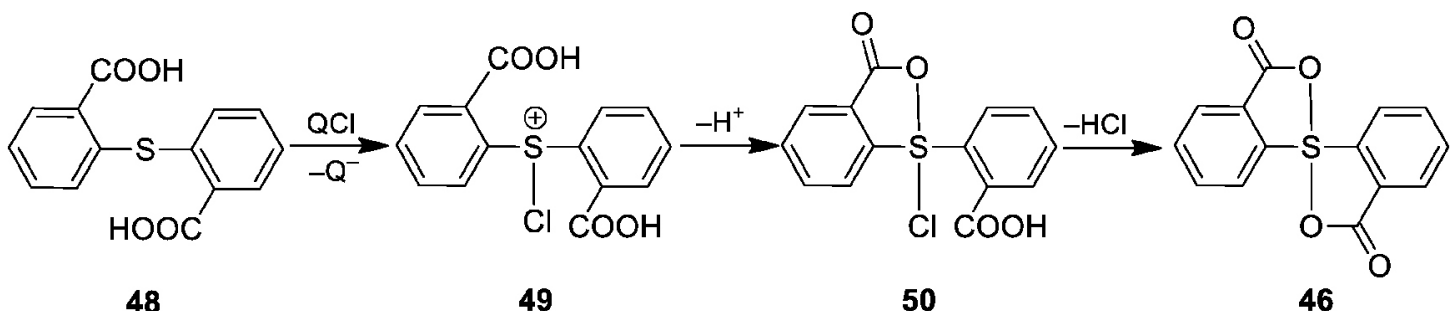

18. Ábra. A diarilbisz(aciloxi)spiro- $\lambda^{4}$-szulfánok előállitása klórozó szerekkel.

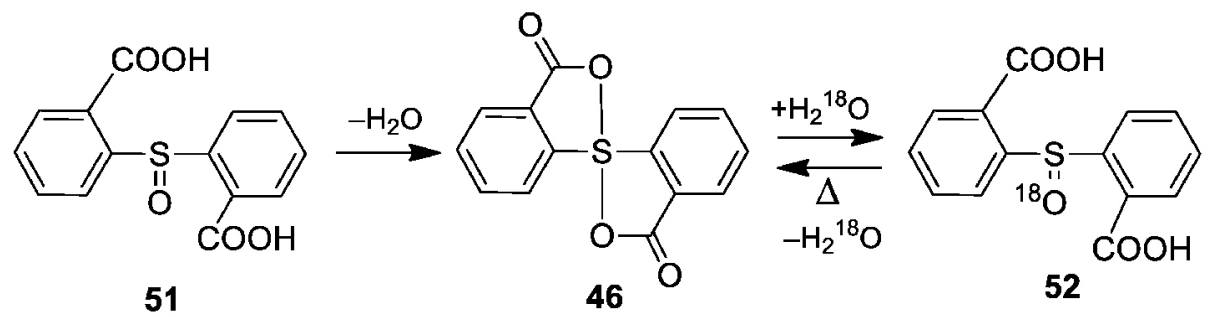

19. Ábra. Diarilbisz(aciloxi)spiro- $\lambda^{4}$-szulfánok szulfoxidokból kiinduló előállítása és hidrolízise. 


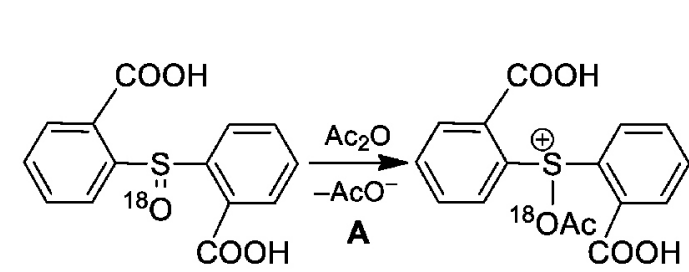

52

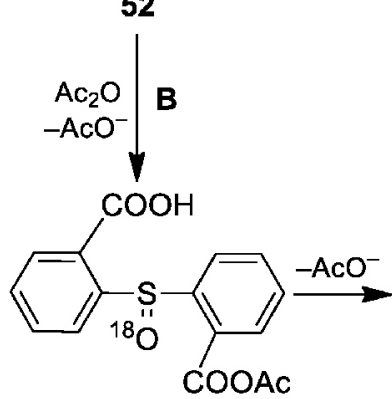

55

53<smiles>CC(C)Cc1ccc(S(=O)(=O)c2ccccc2C(=O)O)c(C(=O)O)c1</smiles>

54<smiles>COS(OC(=O)c1ccccc1C(=O)O)(c1ccccc1)c1ccc(C(F)(F)F)cc1</smiles>

$46 \mathrm{O}$

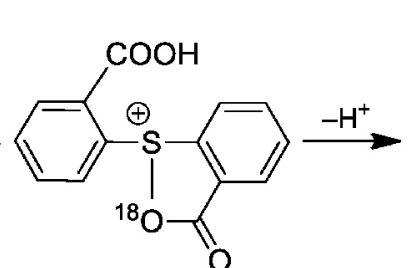

56<smiles>O=C(OS1(Sc2ccccc2)OC(=O)c2ccccc21)c1ccccc1</smiles>

57<smiles>O=C1OS2(OC(=O)c3cc(O)ccc32)c2ccccc21</smiles>

58

20. Ábra. Diarilbisz(aciloxi)spiro- $\lambda^{4}$-szulfánok szulfoxidokból kiinduló szintézisének mechanizmusai.<smiles>Cc1ccccc1C(=O)OS1(C)C(=O)Oc2ccccc21</smiles>

60<smiles>Cc1ccc(C(=O)OCC(C)C)cc1C(=O)O</smiles>

59<smiles>O=C(O)c1ccc2c(c1)C(=O)OC2Sc1ccccc1C(=O)O</smiles>

61

21. Ábra. Alkil-aril-szulfoxidok Pummerer reakciója

képződésére, a termékek ${ }^{18} \mathrm{O}$ izotóptartalma alapján két, a szulfoxid oxigénjének acilezésével (A), illetve vegyesanhidrid képződésével (B) járó mechanizmust lehet javasolni ${ }^{47}$ (20. ábra). Ecetsavban a spiro- $\lambda^{4}$-szulfán apikális helyzetű oxigénatomja és a karbonil között csere (57 5 58) játszódik le. ${ }^{47}$

Az $\alpha$-helyzetben $\mathrm{CH}_{2}$ csoportot tartalmazó szulfoxiddikarbonsavakból (59) nem öt- és hattagú gyürüs spiro- $\lambda 4$-szulfán (60), hanem Pummerer reakcióban öttagú gyürüs lakton (61) keletkezik (21. ábra). ${ }^{47}$

Hattagú gyürüs spiro- $\lambda^{4}$-szulfánokat (63) naftalin gyürün peri-helyzetben karboxilcsoportot tartalmazó szulfidokból (62) és szulfoxidokból (64) lehet szintetizálni az előzőekben tárgyalt módszerekkel (22. ábra). ${ }^{89}$

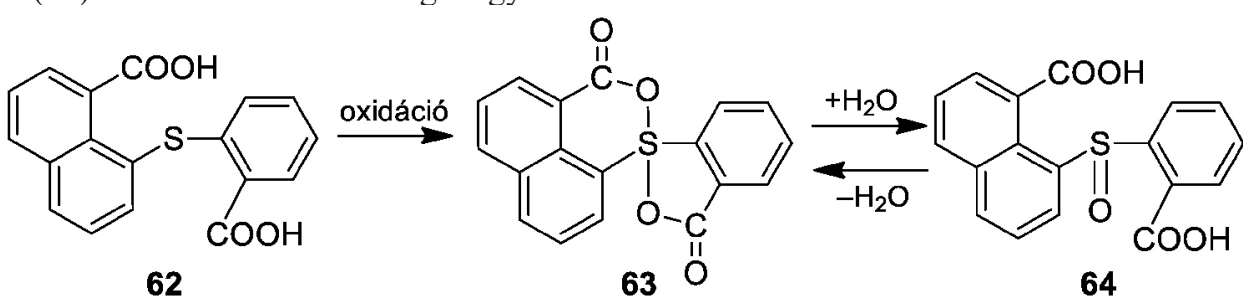

22. Ábra. Hattagú gyürüs spiro- $\lambda^{4}$-szulfánok szintézise. 


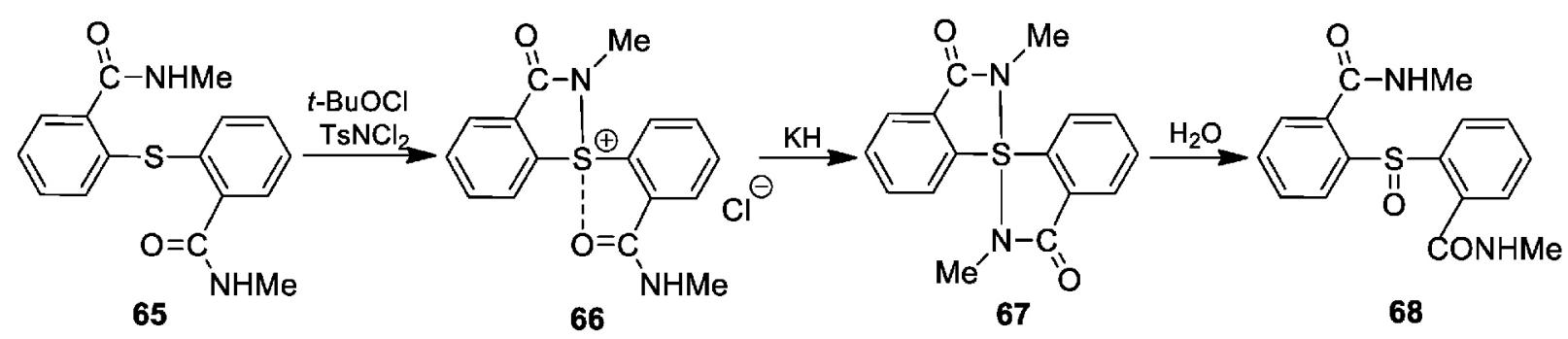

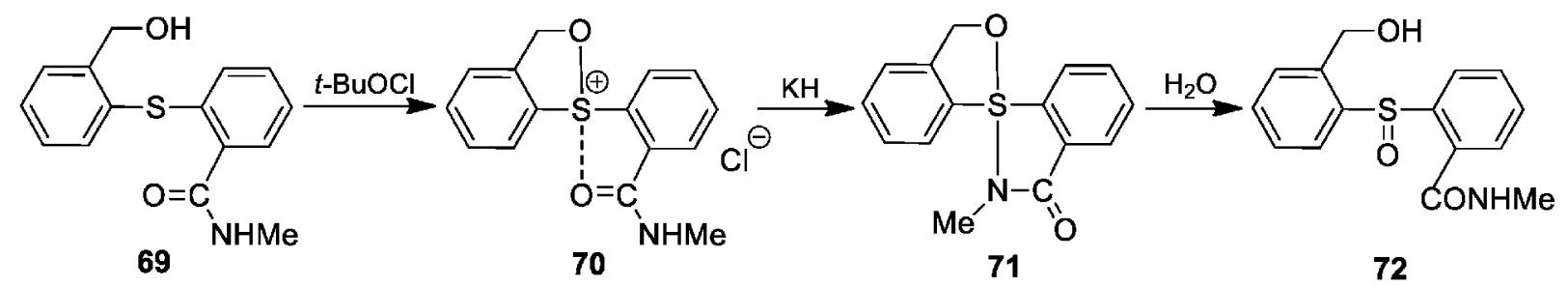

23. Ábra. Bisz(acilamino)- és (acilamino)(alkoxi)spiro- $\lambda^{4}$-szulfánok szintézise.

A CONHMe szomszédcsoportokat tartalmazó diarilszulfidok (65) klórozószerek hatására először TBP geometriájú szulfóniumsókká (66) alakulnak át, amelyeknél az egyik apikális szubsztituens kovalens $\mathrm{S}-\mathrm{N}$ kötéssel, a másik nemkötö $\mathrm{S} \cdots \mathrm{O}$ kölcsönhatással kapcsolódik a szulfónium kénatomhoz (23. ábra). ${ }^{79,112}$ Erös bázissal (KH) a spirogyűrü bezárható, a bisz (acilamino)spiro- $\lambda^{4}$ szulfánokban (67) két nitrogén kötödik a kénatomhoz. A dihidro-1,2-tiazolium és dihidro-1,2-tiazin származékoknak tekinthető szulfóniumsók és a spiro- $\lambda^{4}$-szulfánok vízzel gyorsan szulfoxidokká (68) hidrolizálnak. Analóg módon alkoxi-szulfoniumsók és (acilamino)(alkoxi)spiro- $\lambda^{4}$ szulfánok (69-72) is előállíthatók ${ }^{79,86}$ (23. ábra).

Csak egy CONHMe szomszédcsoportot és egy másik, S $\cdots O O$ kölcsönhatásra nem képes orto szubsztituenst $(\mathrm{X}=\mathrm{H}, \mathrm{MeO}$,
$\mathrm{Me}, \mathrm{Cl}$ ) tartalmazó diaril-szulfidokból (73) klórozószerekkel aprotikus közegben (acilamino)(klór)- $\lambda^{4}$-szulfán (74) keletkezik, ${ }^{120}$ amely protikus közegben a klór disszociációjával szulfónium-kloriddá (75) alakul át (24. ábra). Ha viszont $\mathrm{S} \cdot \cdots O$ kölcsönhatás kialakítására alkalmas másik orto szubsztituens $\left(\mathrm{X}=\mathrm{CO}_{2} \mathrm{Me}, \mathrm{COMe}, \mathrm{NO}_{2}\right)$ van a szulfidon, akkor aprotikus közegben is szulfóniumsó (76) a termék. ${ }^{117,120}$

A CONHMe, $\mathrm{CH}_{2} \mathrm{OH}, \quad \mathrm{SO}_{2} \mathrm{NHMe}$ és $\mathrm{COOH}$ szomszédcsoportokkal vegyesen szubsztituált szulfidokból és szulfoxidokból apikális helyzetben különbözö heteroatomokat tartalmazó, öt- $87,91,101,104,105,107$ és hattagú $79,84-86,93,104$ gyürüs szulfóniumsókat és spiro- $\lambda^{4}$ szulfánokat állítottunk elő (25. ábra).

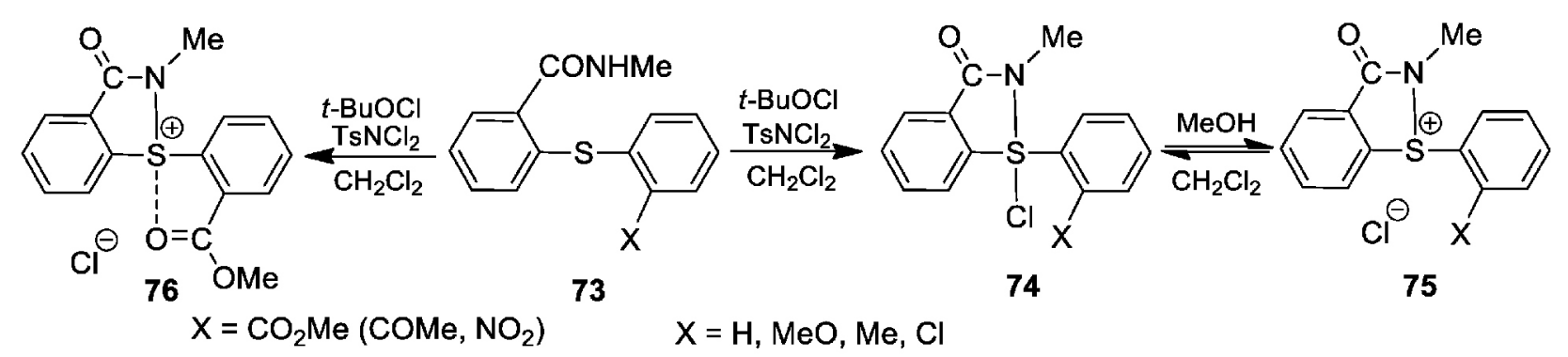

24. Ábra. (Acilamino)(klór)spiro- $\lambda^{4}$-szulfánok és szulfónium-kloridok képződése és egyensúlyai. 

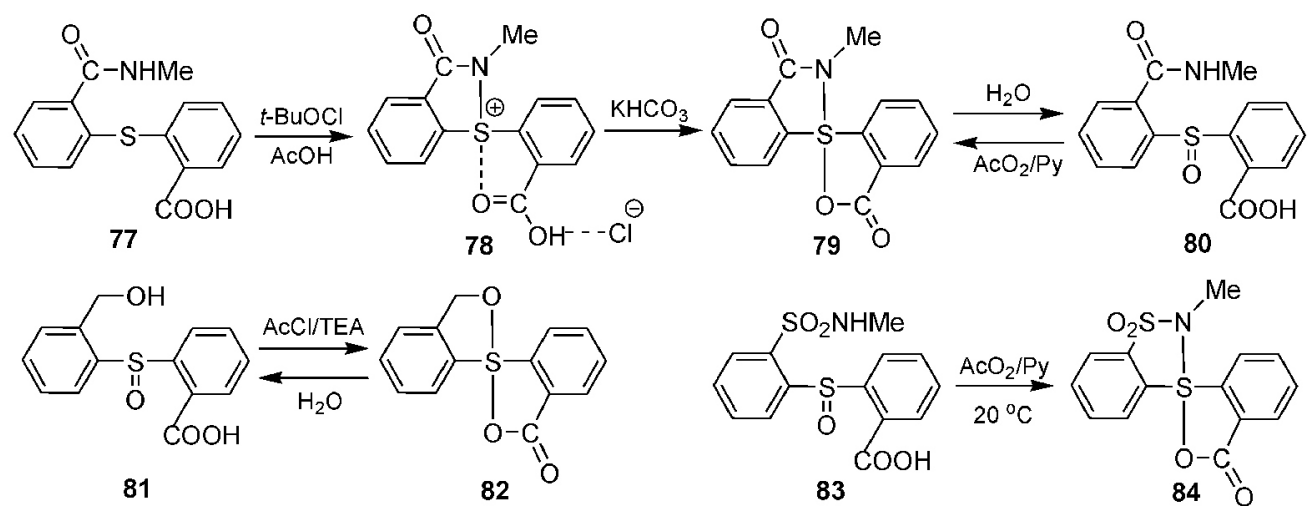
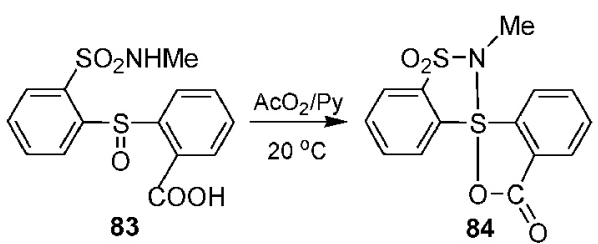

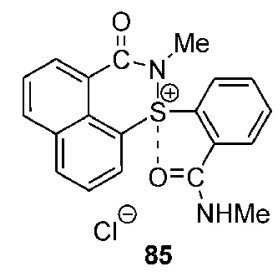<smiles></smiles><smiles>CN=C1C(=O)c2ccccc2[SH]1(=O)c1cccc2cccc(Br)c12</smiles><smiles></smiles><smiles>Cc1ccccc1S1(O)c2cccc3cccc(c23)C(=O)N1C</smiles>

$89 \mathrm{O}$<smiles>C=C(O[SH]1(=O)c2ccccc2C(=O)N1C)c1cccc2ccccc12</smiles>

$90 \mathrm{O}$<smiles>CNC(=O)c1cccc2cccc(S(=O)(=O)c3cccc4cccc(C)c34)c12</smiles><smiles></smiles><smiles>CN1C(=O)c2cccc3cccc(c23)S12OC(=O)c1cccc3cccc(c13)N2C</smiles>

92

25. Ábra. Vegyesen szubsztituált spiro- $\lambda^{4}$-szulfánok és szulfóniumsók előállitása.<smiles>CNC(=O)c1ccc2ccc(C(=O)O)c(S(C)=O)c2c1</smiles>

(S)-(-)-80<smiles>CN(C(=O)c1ccccc1)S1(I)OC(=O)c2ccccc21</smiles>

$(\mathrm{S})-(+)-79$

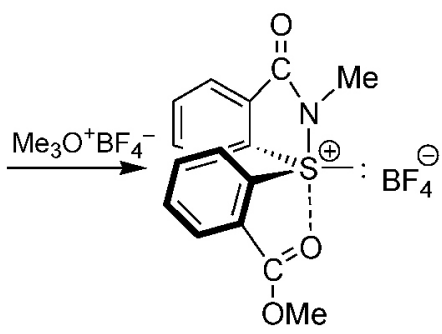

(R)-(+)-93

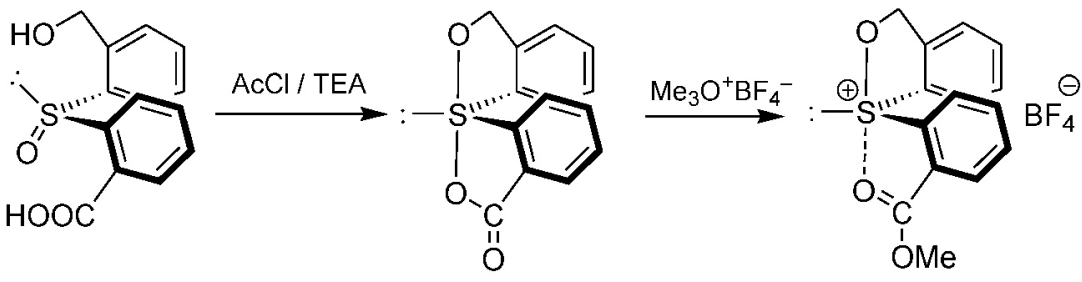

$(\mathrm{R})-(+)-81$

$(\mathrm{R})-(+)-82$

(S)-(-)-94

26. Ábra. Optikailag aktív spiro- $\lambda^{4}$-szulfánok és szulfóniumsók szintézise.

Optikailag aktív diaril-szulfoxidokból ${ }^{109} \quad(\mathbf{8 0}, \quad \mathbf{8 1})$ sztereospecifikus reakciókban optikailag aktív spiro- $\lambda^{4}$-szulfánokat $(\mathbf{7 9}, \mathbf{8 2})$ szintetizáltunk ${ }^{110,119,121}(26$. ábra). A spiro- $\lambda^{4}$-szulfánok karboxilátion jellegú csoportjának $\mathrm{Me}_{3} \mathrm{O}^{+} \mathrm{BF}_{4}^{-}$reagenssel végrehajtott metilezésével pedig optikailag aktív szulfónium sókat (93, 94) készítettünk. A piramisos szulfoxidok és szulfóniumsók sztereokémiai jelölésére a Cahn-Ingold-Prelog konvenciót, a TBP geometriájú spiro- $\lambda^{4}$-szulfánoknál viszont a Martin-Balthazor konvenciót ${ }^{129}$ használtuk.
Az optikailag aktív spiro- $\lambda^{4}$-szulfánok $(\mathbf{7 9}, \mathbf{8 2})$ sztereospecifikus szintéziséhez ${ }^{110}$ az optikailag aktív szulfoxidokat klasszikus rezolválással állítottuk elö. ${ }^{109} \mathrm{~S}$. Allenmark a 46 spiro- $\lambda^{4}$-szulfánt kromatográfiás rezolválással enantiomerekre választotta szét. ${ }^{130}$ Szókán Gyula és munkatársai ${ }^{116}$ a 46 spiro- $\lambda^{4}$-szulfán szubsztituált származékainak, valamint az (alkoxi)(aciloxi)spiro- $\lambda^{4}$ szulfánnak (82) és az (acilamino)(aciloxi)spiro- $\lambda^{4}$ szulfánnak (79) kromatográfiás rezolválását is megoldották. 
Az optikailag aktív szulfoxidok, spiro- $\lambda^{4}$-szulfánok és szulfóniumsók abszolút konfigurációját röntgendiffrakciós ${ }^{109,110}$ és CD spektroszkópiai ${ }^{14,119}$ módszerekkel vizsgáltuk. A CD spektrumok analízisének alapját az adta meg, hogy a TBP geometriájú spiro- $\lambda^{4}$-szulfánok és az analóg térszerkezetű szulfóniumsók színképeiben exciton felhasadások jelentkeznek, amelyekhez tartozó átmeneti momentumok a geometriák hasonlósága miatt azonosak. ${ }^{119}$ A vegyületek abszolút konfigurációját a röntgendiffrakciós mérésekből ismert konfigurációjú szulfánok és szulfóniumsók színképével összehasonlítva, az exciton couplet elöjeléből lehet meghatározni. A probléma megoldására egyszerű szektorszabály is alkalmazható. ${ }^{124} \mathrm{~A}$ magános elektronpár felől nézve a molekulákat és az apikális kötéstengelyt függőlegesen elhelyezve, ha az aromás gyürükkel kondenzált heterogyürü a bal felső és a jobb alsó szektorba esik, akkor a couplet előjele negatív, az ellentétes esetben pedig pozitív (27. ábra).
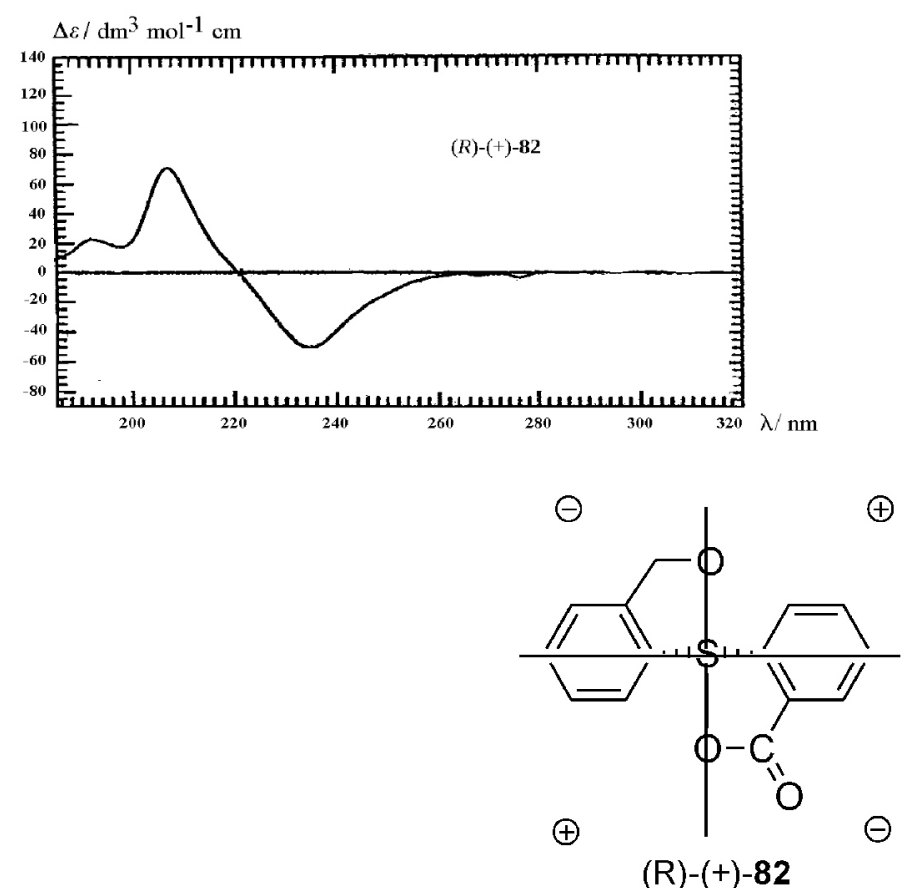

(R)-(+)-82

\section{8. $\lambda^{4}$-Szulfánok és szulfóniumsók szerkezete}

A difenilbisz(aciloxi)spiro- $\lambda^{4}$-szulfán (46) TBP szerkezetét röntgendiffrakciós mérésekkel igazoltuk (28. ábra). ${ }^{24,31} \mathrm{Az}$ ekvatoriális fenilcsoportoknak a kénatommal alkotott kötései a szokásos hosszúságúak, az apikális oxigénatomokat tartalmazó szubsztituensek kötései viszont lényegesen hosszabbak, mint a szokásos egyes kötések. A kénatomot és az apikális helyzetü két heteroatomot 3 centrumos 4 elektronos hipervalens kötés kapcsolja össze lineáris elrendeződésben. Kísérleti ${ }^{24,61,127,128}$ és elméleti ${ }^{67,73,98-100,102,106}$ kutatások arra utalnak, hogy a TBP geometriájú $\lambda^{4}$-szulfánokban és a szulfónium sókban a kén és az apikális helyzetű oxigén, nitrogén vagy klóratomok között egyes és hipervalens kötések, valamint nem kötött kölcsönhatások egyaránt kialakulhatnak. A kötésrendszerben lévő atomok töltése és a kötések polaritása azonos vagy különböző is lehet, ami a kötéstávolságokat jelentősen befolyásolja. A jellemző atomtávolságokat, a kettős kötésekkel és a van der Waals távolságokkal összehasonlítva az 1. táblázat tartalmazza.

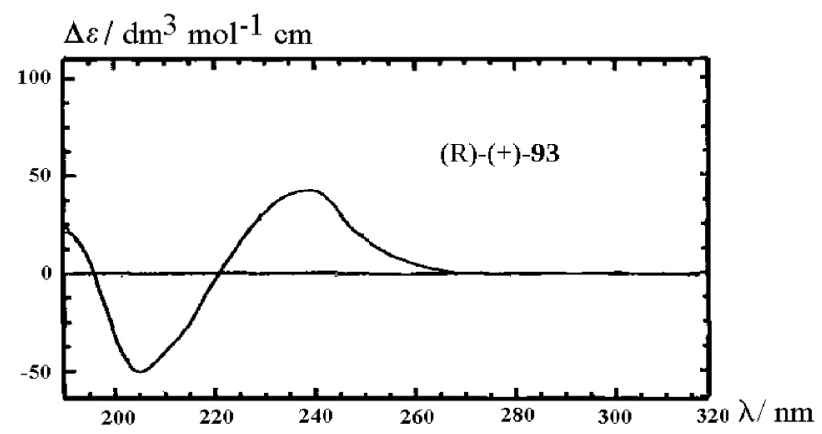

$\oplus$

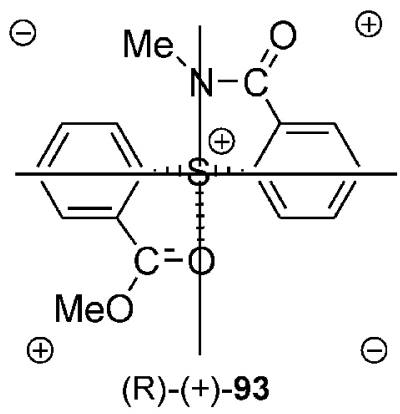

27. Ábra. $(R)-(+)-82$ és $(R)-(+)-93$ CD spektruma és az exiton couplet előjelére vonatkozó empirikus szabály

1. Táblázat. $\mathrm{S}, \mathrm{O}, \mathrm{N}$ és $\mathrm{Cl}$ atomok távolsága szerves kénvegyületekben.

\begin{tabular}{cccc}
\hline Kettős kötés & $\mathrm{S}=\mathrm{O}: 1,40-1,49 \AA$ & $\mathrm{S}=\mathrm{N}: 1,52-1,67 \AA$ & $\mathrm{S}-\mathrm{Cl}: 2,05-2,20 \AA$ \\
Egyes kötés & $\mathrm{S}-\mathrm{O}: 1,56-1,65 \AA$ & $\mathrm{S}-\mathrm{N}: 1,66-1,74 \AA$ & $\mathrm{S}-\mathrm{Cl}: 2,69-3,10 \AA$ \\
Hipervalens kötés & $\mathrm{S}-\mathrm{O}: 1,65-2,25 \AA$ & $\mathrm{S}-\mathrm{N}: 1,73-1,90 \AA$ & $\mathrm{S} \cdots \mathrm{Cl}: 3,18-3,37 \AA$ \\
Nem kötö kölcsönhatás & $\mathrm{S} \cdots \mathrm{O}: 2,03-3,25 \AA$ & $\mathrm{S} \cdots \mathrm{N}: 2,09-2,93 \AA$ & $\mathrm{S} / \mathrm{Cl}: 3.65 \AA$ \\
van der Waals távolság & $\mathrm{S} / \mathrm{O}: 3,25 \AA$ & $\mathrm{S} / \mathrm{N}: 3,35 \AA$ & \\
\hline
\end{tabular}




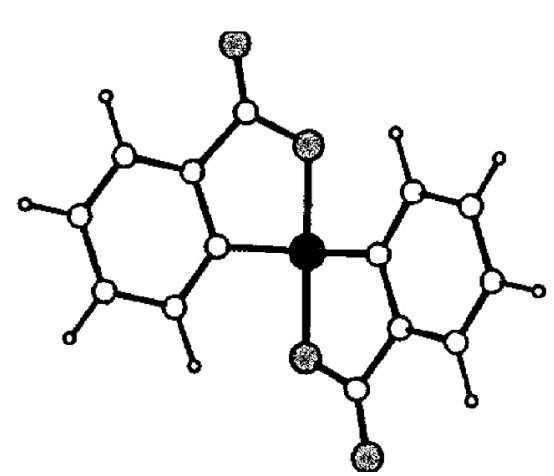

28. Ábra. A difenilbisz(aciloxi)spiro $\lambda^{4}$-szulfán (46) röntgendiffrakciós mérésekkel megállapított szerkezete.

A szimmetrikus spiro- $\lambda^{4}$-szulfánoknak $(46,67)$ tökéletes TBP szerkezete van, ${ }^{89,101,104,107}$ az O-S-O és N-S-N kötések lineárisak. $\mathrm{Az}$ ekvatorilális szubsztituensek közötti $\theta_{1}\left(\mathrm{C}_{\mathrm{Ar}}-\mathrm{S}-\mathrm{C}_{\mathrm{Ar}}\right)$ szögek $120^{\circ}$-nál kisebbek, $102-107^{\circ}$ között változnak a kénatom magános elektronpárjának taszító hatása miatt. A nem szimmetrikus spiro- $\lambda^{4}$-szulfánok ${ }^{79,86}(\mathbf{6 3}, \mathbf{7 1}, \mathbf{7 9}$, $\mathbf{8 2}, 84,86,88-90,92)$ és a klór- $\lambda^{4}$-szulfánok ${ }^{117,120}(\mathbf{7 4})$ torzult TBP struktúrával rendelkeznek, az apikális és ekvatoriális helyzetű csoportok közötti kötésszögek az ideális $180^{\circ}$ és $90^{\circ}$ foktól eltéréseket mutatnak. Meg kell jegyezni viszont, hogy a nem szimmetrikus spiro- $\lambda^{4}$-szulfánok és az ugyancsak TBP struktúrájú, $\mathrm{S} \bullet \bullet \mathrm{O}$ nem kötött kölcsönhatással stabilizált szulfóniumsók ${ }^{79,95}$ között lényeges strukturális eltérés nem mutatkozik.

A bisz(aciloxi)spiro- $\lambda^{4}$-szulfánok ${ }^{79,86,105}$

(46, 63) hipervalens S-O kötései (1,84-1,87 ̊̊) az egyes kötésnél lényegesen hosszabbak, de jelentősen rövidebbek, mint a S••O nem kötött kölcsönhatások. Az (alkoxi)(aciloxi)spiro$\lambda^{4}$-szulfánokban ${ }^{105,110}$ (82) az S-(alkoxi) kötés (1,66-1,71 $\AA$ ) a szokásos egyes kötésnél kissé hosszabb, az S-(aciloxi) kötés $(2,05-2,13 \AA)$ viszont gyenge hipervalens kötésnek bizonyult. A kén-oxigén kölcsönhatással stabilizált alkoxiszulfóniumsókban ${ }^{79,86}$ (70) olyan S-O egyes kötés $(1,62-1,65 \AA$ A $)$ alakul ki, amely a szokatlanul rövid $\mathrm{S} \cdots \mathrm{O}$ kölcsönhatással (2,25-2,35 Å) egy egyenesbe esik.

Az acilamino- $\lambda^{4}$-szulfánokban (67) és az (acilamino)szulfóniumsókban (66) a kén- és nitrogénatomok közötti kötések erőssége a másik apikális helyzetben lévő csoporttól függ. Akkor a legerősebb az S-N kötés (1,68 ̊̊) az (acilamino)szulfónium-sókban, ${ }^{117}$ ha a másik apikális helyzetben nincs szubsztituens $(\mathbf{7 5}, \mathrm{X}=\mathrm{H})$. Gyengébb a kötés, ha a másik apikális helyzetet nem kötött kölcsönhatásban lévő oxigénatom foglalja $\mathrm{el}^{79,86,87,91,117} \quad[\mathbf{7 6}$,

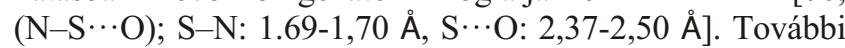
kötésgyengülés lép fel az S-N kötésnél az (acilamino)(aciloxi)-spiro- $\lambda^{4}$-szulfánokban ${ }^{91} \quad[79, \quad(\mathrm{~N}-\mathrm{S}-\mathrm{O}) ; \quad \mathrm{S}-\mathrm{N}$ : 1.71-1,74 $\AA$, S-O: 2,13-2,25 ̊], és a bis(acilamino)- spiro- $\lambda^{4}$ szulfánokban ${ }^{107}[\mathbf{6 7}, \mathbf{8 6},(\mathrm{N}-\mathrm{S}-\mathrm{N})$; S-N: 1.90-1,93 Å]. Ezeknél a vegyületeknél két hipervalens kötés alakul ki a kénatommal.

Az (acilamino)(klór)- $\lambda^{4}$-szulfánokban ${ }^{117,120}$ (74) hipervalens S-Cl kötés (2,69-3,10 ̊̊) van, amely szignifikánsan rövidebb, mint a van der Waals rádiuszok összege, de lényegesen hosszabb, mint az $\mathrm{S}-\mathrm{Cl}$ egyes kötés. A protikus oldószer, vagy az S••• nem kötött kölcsönhatás kiszorítja a klórt a hipervalens S-Cl kötésböl, a molekula szulfóniumsóvá alakul át (75), mert így nagyobb a stabilitása. ${ }^{117} \mathrm{NMR}$ spektroszkópiai vizsgálatok igazolták, ${ }^{120}$ hogy az $\mathrm{X}=\mathrm{Me}, \mathrm{MeO}$, és $\mathrm{Cl}$ szubsztituált (acilamino)(klór)- $\lambda^{4}$-szulfánokban (74) a két aromás gyürü síkja egymásra merőleges, a molekuláknak csavart konformációja van. Az orto szubsztituenst nem tartalmazó vegyületnél $(\mathbf{7 4}, \mathrm{X}=\mathrm{H})$ viszont a monoszubsztituált aromás gyürü szabadon forog. A szulfónium-sóvá alakuló $\mathrm{X}=$ COOMe, CONHMe, COMe, vagy $\mathrm{NO}_{2}$ szubsztituált származékoknak (76) TBP szerkezete ${ }^{79,86,91}$ van, mert S•••O nem kötött kölcsönhatás alakul ki a szubsztituens oxigénatomja és a kénatom között. ${ }^{117,120}$ A kölcsönhatásban szereplő oxigénatom a kénatom negyedik szubsztituense, az N-S••O atomok lineáris elrendeződésben vannak. $\mathrm{Az}$ (acilamino)szulfónium-sóknál ${ }^{79,112}(\mathbf{7 5})$ a pozitív töltésű $\mathrm{S}^{+}$ centrum és a klór ellenion távolsága 3,18-3,37 Å közé esik, az $\mathrm{C}_{\mathrm{Ar}}-\mathrm{S}^{+} \cdot \bullet \mathrm{Cl}^{-}$atomok elrendeződése a lineárishoz közel áll $\left(169-174^{\circ}\right)$, a $\theta_{1}\left(\mathrm{C}_{\mathrm{Ar}}-\mathrm{S}-\mathrm{C}_{\mathrm{Ar}}\right)$ szög $102^{\circ}$, a $\theta_{2}\left(\mathrm{~N}-\mathrm{S}-\mathrm{C}_{\mathrm{Ar}}\right)$ szög pedig $92-103^{\circ}$ között változik. Az analóg felépítésű alkoxiszulfónium-sók ${ }^{86,105}$ (70) szerkezete és kötésszögei nem mutatnak lényeges eltérést az előzőektől.

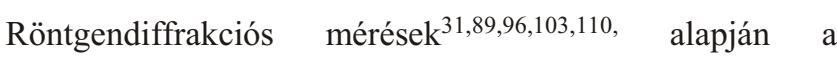
molekulák aromás gyürüi és az öttagú heterciklusos gyürük kevés eltéréssel planárisak. A hattagú heterociklusos gyürük a molekula szerkezetétől függően torzult félszék vagy kád konformációt vehetnek fel. A $\lambda 4$-szulfánokban és szulfóniumsókban az aromás gyürük konformációja a $\mathrm{C}_{\mathrm{Ar}}-\mathrm{S}-\mathrm{C}_{\mathrm{Ar}}$, atomok által alkotott síkhoz képest elfoglalt helyzetükkel jellemezhető. 58,79,89,91,107, Az öttagú gyürüs spiro- $\lambda^{4}$-szulfánokban $(46,67,71,79,82)$ az aromás gyürük a megadott síkra merőlegesek, a molekulának pillangó konformációja van. Hattagú heterogyürüket tartalmazó spiro- $\lambda^{4}$-szulfánoknál $(\mathbf{6 3}, \mathbf{8 6}, \mathbf{8 8 - 9 0}, 92)$ a pillangó konformáció torzulásával kell számolni. Hasonló szabályok érvényesülnek a nemkötő kölcsönhatást nem létesítő csoportokkal rendelkező szulfóniumsók esetében is.

\section{9. $\lambda^{4}$-Szulfánok és szulfóniumsók hidrolízisének mechanizmusa}

A $\lambda^{4}$-szulfánok és szulfóniumsók szerkezete és reakciókészsége közötti összefüggéseket a hidrolízisek mechanizmusának felderítésével vizsgáltuk.

Az öttagú gyürüs diarilbisz(aciloxi)spiro- $\lambda$ 4-szulfánok (95) hidrolízisének ${ }^{90}$ döntő lépése az egyik hipervalens S-O kötés egyensúlyi felhasadása (29. ábra). A reakciót az aromás gyürün lévő elektronküldő csoportok $(\rho=-0,52)$ és az oldószer ionizáló erejének növekedése segítik elő. A keletkező zwitterion intermedier (96) azonban a karboxilát ionnak a szulfónium centrumon lejátszódó támadásával nagyon könnyen visszazár a kiindulási spiro- $\lambda^{4}$-szulfánná (95). Ez a reakciólépés az öttagú gyürü képződése és az ellentétes elektromos töltések miatt rendkívül gyors. A hidrolízis csak a víznek, a nagyon rövid élettartamú zwitterion intermedier (96) pozitív töltésű kénatomján végbemenő támadásával mehet végbe. Erős savak a zwitterion karboxilát ionjának protonálásával katalizálják a reakciót. A keletkező aciloxiszulfónium-sók vízzel nagyon gyorsan átalakulnak szulfoxiddá (98). Az észlelt kis 
oldószer-izotópeffektus $\left[k\left(\mathrm{H}_{2} \mathrm{O}\right) / k\left(\mathrm{D}_{2} \mathrm{O}\right)=1,66\right]$ igazolja, hogy a protonátmenetek nem tartoznak a sebességmeghatározó-lépéshez. Az ötnél nagyobb tagszámú gyürüt tartalmazó bisz(aciloxi)- $\lambda^{4}$-spiroszulfánok hidrolízisének sebessége nagyobb, mint az öttagú gyürüseké. Az S-O kötések erőssége ${ }^{89}$ és a zwitterion visszazáródási sebessége a spirogyürü növekedésével csökken, ami a zwitterion intermedier élettartamát, és a hidrolízis sebességét növeli.

A diaril(acilamino)(aciloxi)spiro- $\lambda^{4}$-szulfánoknak ${ }^{91}$ erős S-N kötése és poláris, hipervalens $\mathrm{S}-\mathrm{O}$ kötése, a szulfónium-karboxilát zwitterionhoz hasonló szerkezete van. Öttagú gyürüs acilamino csoportot tartalmazó származékoknál ${ }^{108}$ a reakció sebességét az aromás gyürühöz kapcsolódó elektronvonzó csoportok növelik $(\rho=1,43)$ és primer kinetikus izotópeffektus jellemzi a reakciót $\left[k\left(\mathrm{H}_{2} \mathrm{O}\right) / k\left(\mathrm{D}_{2} \mathrm{O}\right)=3,68\right]$. Az aciloxi csoport protonálásával a hidrolízist erős savak katalizálják. Mivel a kén-oxigén kötés gyenge és ezért az aciloxi csoportot tartalmazó gyürü felnyílása nagyon gyors folyamat, a reakció sebességmeghatározó-lépése a víz protonátmenettel együtt járó támadása a pozitívan polározott kénatomon (100). A hattagú gyürübe zárt acilamino viszont gyengébb távozó csoport. Az ilyen származékok reakciókészsége vízzel szemben lényegesen kisebb, mint az öttagú gyürüseké. Hidroxidionokkal azonban ezek a vegyületek is gyorsan reagálnak, a hidrolízis sebessége vizes oldatban egy-egy nagyságrenddel nő a $\mathrm{pH}$ növekedésével.

A diarilbisz(acilamino)spiro- $\lambda^{4}$-szulfánok (103) hidrolízisénél a sebességmeghatározó-lépésben az egyik hipervalens S-N kötés felhasad, és proton megy át egy vízmolekuláról a nitrogénatomra ${ }^{113}$ (31. ábra).<smiles>[X]c1ccc(S(C)(=O)(O)c2ccc(C(C)(C)C)cc2C(=O)O)c(C(=O)O)c1</smiles>

95<smiles>Cc1ccc(S2(c3ccc(O)cc3)OC(=O)c3ccccc32)c(C(=O)O)c1</smiles>

96<smiles>[X]c1ccc(S(C)(O)c2ccccc2C(=O)O)c(C=O)c1</smiles>

97

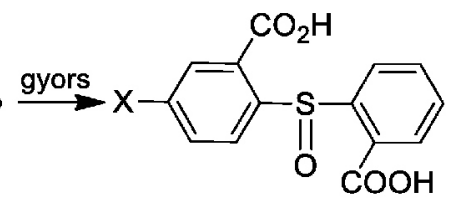

98

29. Ábra. Bisz(aciloxi)- $\lambda^{4}$-spiroszulfánok hidrolízisének mechanizmusa

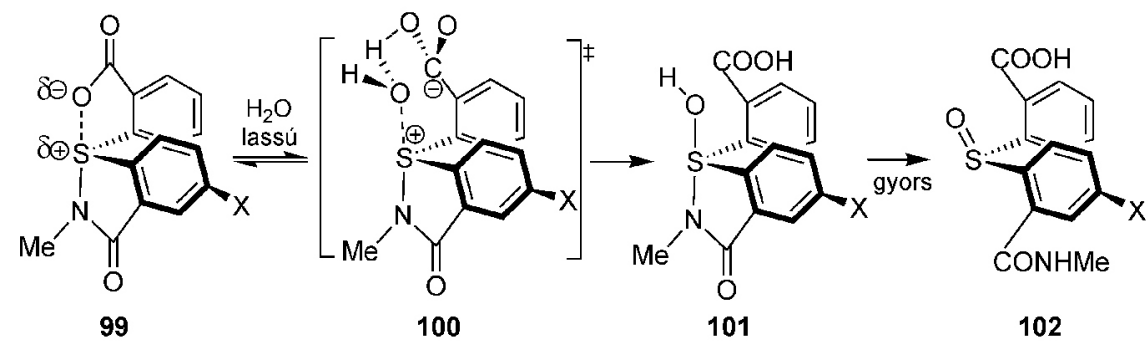

30. Ábra. Diaril(acilamino)(aciloxi)- $\lambda^{4}$-spiroszulfánok hidrolízisének mechanizmusa.<smiles>CN1C(=O)c2ccccc2[SH]1(=O)c1ccccc1</smiles>

103<smiles>C[C@@H](O)CC1CC1</smiles><smiles>C[C@H](O)N(C)S(=O)(=O)c1ccccc1C(=O)N(C)C(=O)c1ccccc1</smiles><smiles>CNC(=O)c1ccccc1C(=O)N1C(=O)c2ccccc2S1(=O)=O</smiles>

108
104

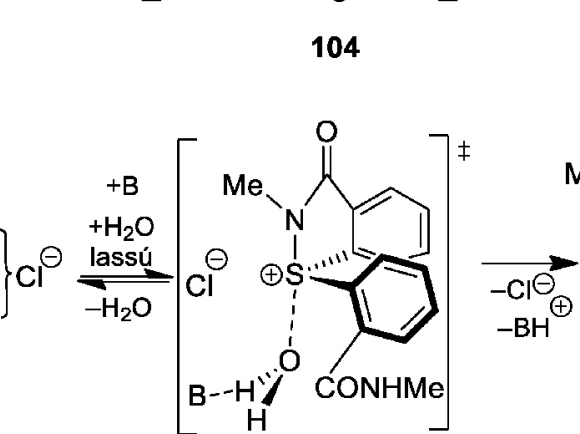

109<smiles>CNC(=O)c1ccccc1C(=O)N1CCCC1C(=O)O</smiles><smiles>[AsH3-][AsH3-]</smiles><smiles>CNC(=O)c1ccccc1S(O)(O)c1ccccc1C(=O)O</smiles>

106

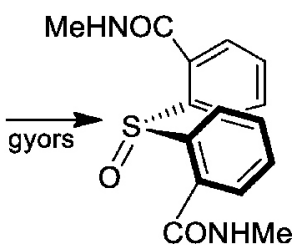

107

31. Ábra. Diarilbisz(acilamino)- $\lambda^{4}$-spiroszulfánok hidrolízisének mechanizmusa. 


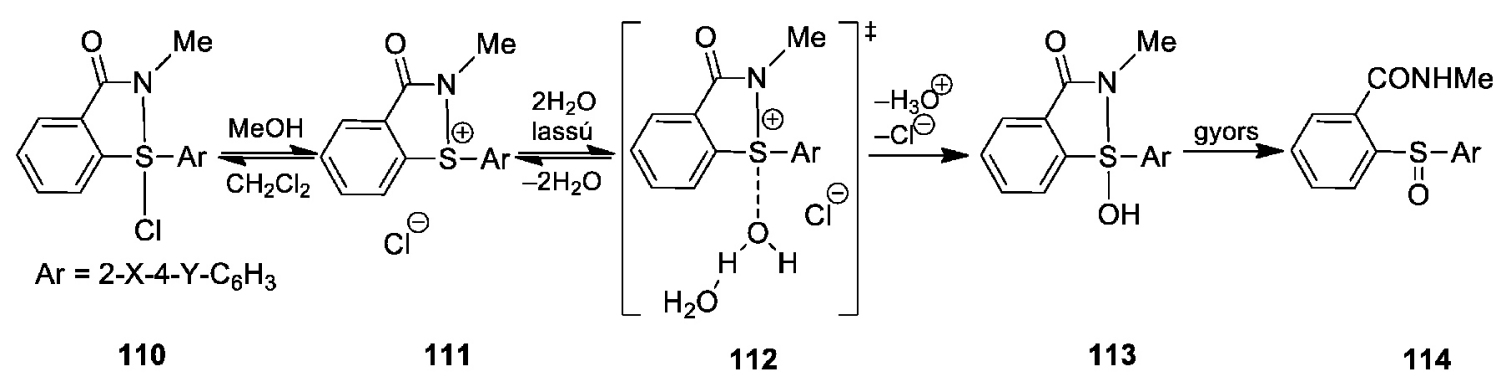

32. Ábra. 1,2-tiazolin gyürüs (acilamino)(klór)- $\lambda 4$-szulfánok hidrolízisének mechanizmusa.

$\mathrm{Az}$ egyidejűen képződött hidroxidion támadja a szulfóniumion (105) pozitív töltésű kénatomját és diaril(acilamino)(hidroxi)- $\lambda^{4}$-szulfánon (106) keresztül szulfoxid (107) keletkezik. A mechanizmust az észlelt szubsztituens hatás $\left(\rho^{+}=-0,44\right)$ és az oldószer izotópeffektus $\left[k\left(\mathrm{H}_{2} \mathrm{O}\right) / k\left(\mathrm{D}_{2} \mathrm{O}\right)=1,8-2,0\right]$, valamint az unimolekuláris reakcióra utaló magas aktiválási entrópia érték $\left(\Delta H^{*}=78,7 \mathrm{Jmol}^{-1}, \Delta S^{\star}=-25,1 \mathrm{Jmol}^{-1} \mathrm{~K}^{-1}\right)$ is alátámasztja. Az öt- és hattagú gyürüt egyaránt tartalmazó diarilbisz(acilamino)spiro- $\lambda^{4}$-szulfán gyorsabban hidrolizál mint a csak öttagú gyürüt tartalmazó vegyület, mert a hattagú spirogyürü könnyebben nyílik fel és nehezebben zárul vissza az első egyensúlyi lépésben.

Az orto helyzetben karbamoil csoporttal szubsztituált gyürüs diaril(acilamino)szulfóniumsók (108) híg oldatban egyensúlyban $\operatorname{vannak}^{113}$ a bisz(acilamino)spiro- $\lambda^{4}$ szulfánokkal (103). Savas közegben azonban az egyensúly teljesen a szulfóniumsó felé tolódik el. A szulfóniumsókban a karbamoil-csoport oxigénatomja nemkötő kölcsönhatásban van a szulfónium-kénatommal (31. ábra). A szulfóniumsók (108) mintegy 25-ször lassabban hidrolizálnak, mint a bisz(acilamino)spiro- $\lambda^{4}$-szulfánok (106). A hidrolízist a savak nem, de a bázisok, pl. az acetátionok katalizálják. A vízzel és hidroxidionokkal lejátszódó reakció sebessége a pH növekedésével nő. Elektronvonzó csoportok gyorsítják a hidrolízist, a primer deutérium oldószer-izotópeffektus értéke az átmeneti állapotban végbemenő jelentős protonátmenetre utal $\left[k\left(\mathrm{H}_{2} \mathrm{O}\right) / k\left(\mathrm{D}_{2} \mathrm{O}\right)=4,4\right]$. A sebességmeghatározó lépésben vízmolekula támadja a szulfónium kénatomot (109), a bázis protont szakít le a vízröl, és (acilamino)(hidroxi)- $\lambda^{4}$-szulfán (106) intermedieren keresztül alakul ki a szulfoxid (107) végtermék (31. ábra).

NMR vizsgálatok bizonyították, hogy az (acilamino)(klór)- $\lambda^{4}-$ szulfánok (110) csak aprotikus oldószerben létképesek, protikus oldószerekben azonnal acilamino-szulfónium kloridokká (111) alakulnak át. ${ }^{120}$ Az öttagú 1,2-tiazolin gyürüt tartalmazó szulfóniumsók vízzel olyan gyorsan hidrolizálnak, hogy szokásos módszerekkel csak az igen kevés vizet tartalmazó dioxán-víz elegyekben (2-4 \%) lehet a reakció sebességét mérni. A reakciót elektronvonzó csoportok gyorsítják $(\rho=1,03)$, a primer deutérium kinetikus oldószer izotópeffektus értéke $\left[k\left(\mathrm{H}_{2} \mathrm{O}\right) / k\left(\mathrm{D}_{2} \mathrm{O}\right)=3\right]$ sebességmeghatározó protonátmenetre, az aktiválási paraméterek bimolekuláris sebességmeghatározó lépésre utalnak $\left(\Delta H^{*}=\right.$ $\left.30,5 \mathrm{Jmol}^{-1}, \Delta \mathrm{S}^{\ddagger}=-202 \mathrm{Jmol}^{-1} \mathrm{~K}^{-1}\right)$. Az orto helyzetü karbonilcsoportot tartalmazó szubsztituensek csökkentik a reakció sebességét a karbonil oxigén és a szulfónium kénatom között kialakuló nemkötő kölcsönhatás révén. A reakció sebességmeghatározó-lépésében a víz támadja a szulfónium centrumot (112), protonátmenettel (acilamino)(hidroxi)- $\lambda^{4}$-szulfán (113) keletkezik, amely szulfoxiddá (114) alakul át (32. ábra).

A hattagú 1,2-tiazin gyürüt tartalmazó acilaminoszulfóniumsók (115) hidrolízise ${ }^{120}$ lényegesen lassúbb folyamat, mint az 1,2-tiazolin gyürüs (111) származékoké. A reakció sebessége vizes oldatban mérhető és a $\mathrm{pH}$ növekedésével nő. Csak a hidroxidion tudja eredményesen támadni a molekulát, mert a hattagú gyürüben lévő $\mathrm{S}-\mathrm{N}$ kötés az öttagú gyürübe zártnál rövidebb és erősebb. Az oldószer izotópeffektus alapján $\left[k\left(\mathrm{H}_{2} \mathrm{O}\right) / k\left(\mathrm{D}_{2} \mathrm{O}\right)=6,5\right]$ a szulfoxid termék (118) az (acilamino)(hidroxi)- $\lambda^{4}$-szulfán intermedierből (116) protonátmenettel keletkezik (33. ábra). Az aktiválási paraméterek oldószer molekulákkal támogatott unimolekuláris reakcióra utalnak $\left(\Delta H^{\star}=78,7 \mathrm{Jmol}^{-1}, \Delta S^{\ddagger}=\right.$ $\left.-45,9 \mathrm{Jmol}^{-1} \mathrm{~K}^{-1}\right)$.

A szulfánok és szulfóniumsók hidrolizisének sztereokémiáját optikailag aktív vegyületeken vizsgáltuk. A reaktánsok és a termékek abszolút konfigurációját $\mathrm{CD}$ és NMR spektroszkópiai módszerek alkalmazásával határoztuk meg. $\mathrm{Az}$ (acilamino)(aciloxi)-spiro- $\lambda^{4}$-szulfánok (119), valamint a COOMe szomszédcsoporttal szubsztituált acilaminoszulfóniumsó ${ }^{118,119,121}$ származékaik (123) savas és bázikus közegben ugyanolyan konfigurációjú szulfoxiddá $(121,122)$ hidrolizálnak (34. ábra). A szulfóniumsók (123) hidrolízisénél $\mathrm{S}_{\mathrm{N}} 2$ reakció játszódik le, mert az észter karbonilcsoportja és a szulfónium kénatom közötti gyenge nemkötő kölcsönhatás könnyen felszakad, és a hidroxidion vagy a víz csak hátoldalról támadhatja a szulfónium centrumot. Az aciloxi csoportot tartalmazó (acilamino)(aciloxi)spiro- $\lambda^{4}$-szulfánok (119) gyenge hipervalens kén-oxigén kötése szintén nagyon könnyen felszakad. A képződött zwitterion jellegű szulfóniumsó (120) vízzel vagy hidroxidionnal, savas vagy bázikus közegben egyformán, $\mathrm{S}_{\mathrm{N}} 2$ reakcióban alakul át szulfoxiddá.

$\mathrm{Az}$ (alkoxi)(aciloxi)-spiro- $\lambda^{4}$-szulfánokból (124) és az alkoxiszulfónium sókból (127) bázikus közegben ugyanolyan konfigurációjú szulfoxid keletkezik (125, 126). ${ }^{118,119,121} \mathrm{Az}$ eredmény a szulfán aciloxi csoportot tartalmazó gyürüjének felnyílásával magyarázható, mert az intermedierként keletkező és a modellként használt alkoxiszulfóniumsók konfigurációja azonos. Az (alkoxi)(aciloxi)-spiro- $\lambda^{4}$-szulfánok (124) savas közegben lejátszódó reakciója azonban az előbbivel ellentétes konfigurációjú termékhez (129) vezetett (35. ábra). 


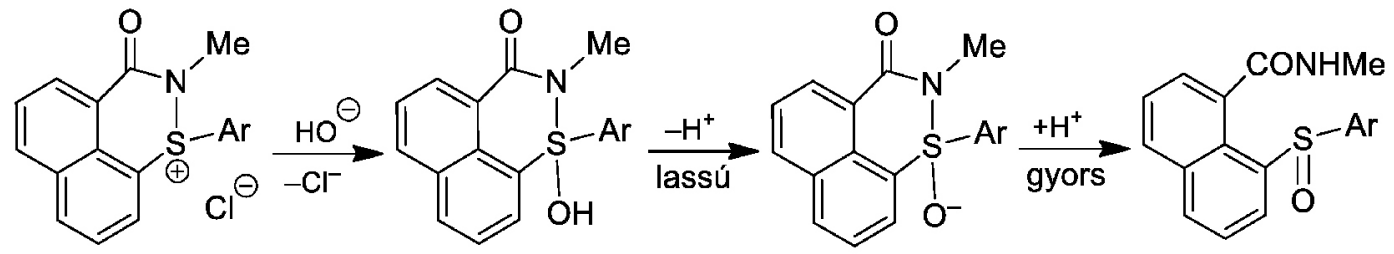
$\mathrm{Ar}=2-\mathrm{X}-\mathrm{C}_{6} \mathrm{H}_{4}$ 115 116

117

33. Ábra. 1,2-tiazin gyürüs acilamino-szulfoniumsók hidrolízisének mechanizmusa.

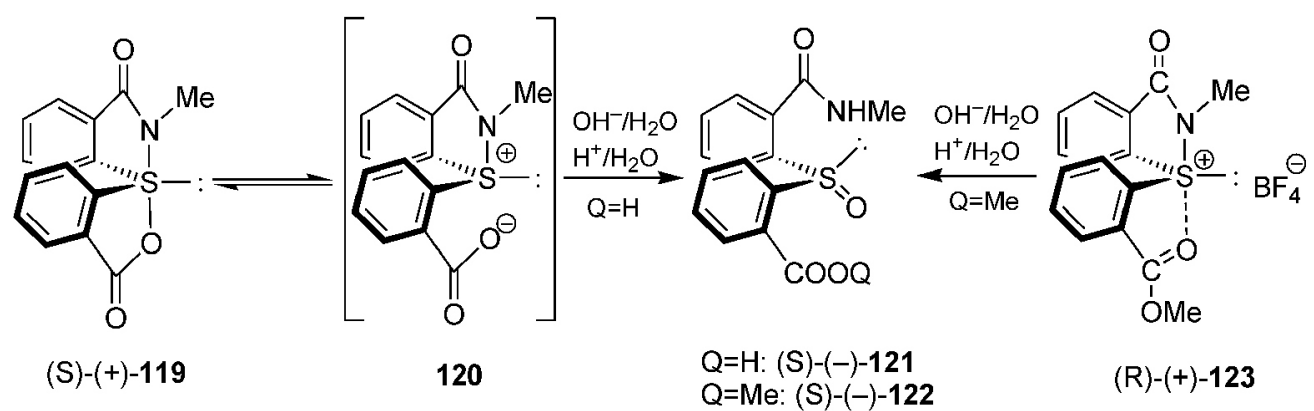

34. Ábra. (Acilamino)(aciloxi)-spiro- $\lambda^{4}$-szulfánok és acilamino-szulfóniumsók hidrolízisének sztereokémiája.

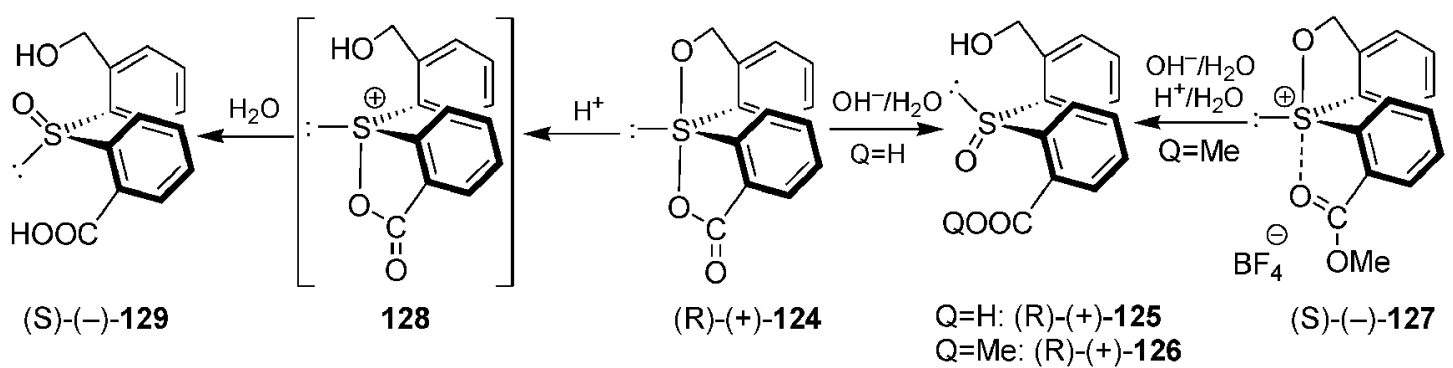

35. Ábra. (Alkoxi)(aciloxi)-spiro- $\lambda^{4}$-szulfánok és alkoxiszulfóniumsók hidrolízisének sztereokémiája.

Az eredmények alapján savanyú közegben az alkoxi csoportot tartalmazó gyürü nyílik ki, és az aciloxiszulfónium kationon (128) megy végbe a konfiguráció inverziójával járó $\mathrm{S}_{\mathrm{N}} 2$ reakció.

\section{Kén-oxigén kölcsönhatások}

A kén-oxigén kölcsönhatások területére olyan vonzó szekunder kölcsönhatásokat sorolunk, amelyeknél a molekulákban közvetlenül kötésben nem lévő kén- és oxigénatomok egymáshoz képest a van der Waals távolságnál (3.35 ̊̊) közelebb vannak. Akceptorként a kölcsönhatásban a szulfidok, diszulfidok, szulfenátok, szulfóniumsók és szulfoxidok kénatomja, donorként a karbonilcsoportok, valamint a nitro- és a nitrózócsoport oxigénatomja szerepelhet.

A kén- és oxigénatomok közötti vonzó kölcsönhatások kialakulásának szerkezeti feltételeit röntgen- és elektrondiffrakciós vizsgálatok eredményeinek elemzése alapján tapasztalati szabályokba foglaltuk össze. ${ }^{61} \mathrm{~A}$ kölcsönhatásban lévő atomok távolságát a kovalens és hipervalens kötések hosszával, valamint a van der Waals távolsággal együtt tárgyaltuk. Különösen érdekes tapasztalatokat eredményezett kén-oxigén nemkötő kölcsönhatások és a hipervalens kötések tartományának összevetése, mert ezek átfedésben vannak egymással. Esetenként az erős nemkötő kölcsönhatás kisebb kén-oxigén távolságot eredményezhet, mint a gyenge hipervalens kötés. A hipervalens kén-oxigén kötések és a kén-oxigén kölcsönhatások hossza ugyanis számottevően függ a kénhez kovalens kötéssel kötődő, az oxigénnel ellentétes helyzetü apikális atom vagy csoport elektronegativitásától.

A kén-oxigén kölcsönhatások kialakulásának, tapasztalatok alapján megfogalmazott feltételei a következők.

1. A kötésben nem lévő kén- és oxigénatom 1,5-helyzetet foglaljon el (36. ábra).

2. A kén- és oxigénatomot összekötő $\mathrm{sp}^{2}$ hibridállapotú szénvagy nitrogénatomok ( $\mathrm{A}, \mathrm{B}, \mathrm{C})$ folytonos konjugációt biztosítsanak, az $\mathrm{S}-\mathrm{A}=\mathrm{B}-\mathrm{C}=\mathrm{O}$ kötésrendszer az $\mathrm{X}$ csoporttal együtt egy síkban helyezkedjen el.

3. Az X, S, és O atomok lineáris elrendeződésben legyenek.

4. Az X atom vagy csoport elektronegativitásának növekedése segíti a nemkötő kölcsönhatás kialakulását és erősségének növekedését, ami a kén-oxigén távolság csökkenésében nyilvánul meg. 


$$
\begin{array}{rl}
X-S \cdots \cdots . O & X=C_{2}, N R_{2}, S R, O R, C l, F \\
A_{\text {:B-C }}{ }^{-C} Z & A, B, C=C\left(s^{2}\right), N\left(s^{2}\right) \\
& \left.Z=H, R, N R_{2} \text { OR, elektronpár [ha } C=N\left(s^{2}\right)\right]
\end{array}
$$

36. Ábra. A kén-oxigén kölcsönhatás tapasztalati szerkezeti feltételei.

A szabályok érvényesülését ismert szerkezetű anyagok adatainak elemzése ${ }^{61}$ mellett tervezett szerkezetű vegyületek előállításával és struktúrájuk röntgendiffrakciós ${ }^{57,58,62,75,76,86}$ vagy elektrondiffrakciós meghatározásával is alátámasztottuk. Az orto-nitrobenzolszulfenilklorid (128) és az orto-nitrofenilmetil-szulfid (129) elektrondiffrakciós vizsgálata ${ }^{56,69}$ igazolta például, hogy a nemkötő kölcsönhatásban lévő kén- és oxigénatom távolsága a háttératom vagy csoport ( $\mathrm{X}=\mathrm{Cl}$ és $\mathrm{CH}_{3}$ ) elektronegativitásának növekedésével csökken és a háttératom, valamint a kén és oxigénatomok lineáris elrendeződése minden esetben megvalósul.<smiles>[Z14][R5]([3H])(Cl)c1ccccc1[N+](=O)[O-]</smiles>

128

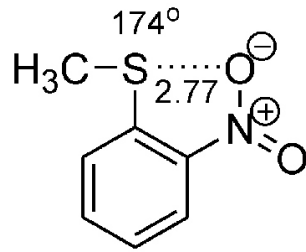

129
37. Ábra. Kén-oxigén kölcsönhatás az orto-nitrobenzolszulfenilkloridban (128) és az orto-nitrofenil-metil-szulfidban (129).

A kvantumkémia ab initio számítási módszereinek alkalmazása ${ }^{60,67,71,73}$ a modellvegyületek szerkezetének egyszerüsítését és tervszerü változtatását, sorozatok vizsgálatát, a kén-oxigén kölcsönhatásra vonatkozó szabályok kvantitatív leírását tette lehetővé. Négy egyszerű sorozatot választottunk (38. ábra). A kölcsönhatásért felelős oxigénatomot a formil-, a nitro- vagy a nitrózócsoport adta (130-133). A formilcsoportot tartalmazó sorozatnál az összekötő lánc középső szénatomját nitrogénatomra is kicseréltük $(\mathbf{1 3 0}, \mathbf{1 3 1})$. A háttércsoportot $(\mathrm{X})$ az elektronegativitás csökkenésének sorrendjében változtattuk (38. ábra). A kölcsönhatás kvantitatív értékelésére az eredményeket a formil- és a nitrózó-csoportot (130-132) tartalmazó sorozatokban az s-cisz és s-transz konformerek adatainak összevetésével is megvizsgáltuk.

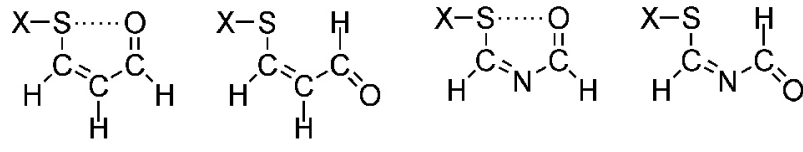

$$
\begin{aligned}
& \text { s-cisz-130 s-transz-130 s-cisz-131 s-transz-131 }
\end{aligned}
$$

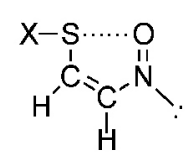

s-cisz-132<smiles>[X]S/C=C\[N+](C)=O</smiles><smiles></smiles>

133
38 Ábra. Modellsorozatok a kén-oxigén kölcsönhatás kvantumkémiai számítására $\left(\mathrm{X}=\mathrm{F}, \mathrm{OH}, \mathrm{NH}_{2}, \mathrm{CH}_{3}, \mathrm{SH}\right)$.
A kén-oxigén kölcsönhatás kvantitatív leírására az alábbi paramétereket találtuk alkalmasnak.

1. A kölcsönhatásban részt vevő oxigén kettős kötésének hosszabbodása az s-transz $\rightarrow$ s-cisz konformációváltozásnál $\left[\Delta \mathrm{r}(\mathrm{Y}=\mathrm{O})=\mathrm{r}(\mathrm{Y}=\mathrm{O})_{\mathrm{s}-\mathrm{cisz}}-\right.$ $\mathrm{r}(\mathrm{Y}=\mathrm{O})_{\mathrm{s}-\text { transz }}, \mathrm{Y}=\mathrm{C}$ vagy $\left.\mathrm{N}\right]$.

2. A kölcsönhatásban lévő kén és oxigén atomok távolsága $[\mathrm{r}(\mathrm{S} \cdots \mathrm{O})]$.

3. Az s-transz $\rightarrow$ s-cisz konformáció-változáskor bekövetkező energiacsökkenés $(\Delta E)$.

4. A ,nemkötőnek" nevezett kölcsönhatásban lévő kénés oxigénatomok közötti kovalens kötésre számítható Mayer-féle kötésrend adat. ${ }^{131}$

A kvantumkémiai számítások alapján kapott adatok jól jellemzik a kén-oxigén kölcsönhatásokat és igazolják a korábbi kvalitatív szabályokat.

1. Planáris folytonosan konjugált rendszer alakul ki.

2. Az X, S, O atomok lineáris elrendeződésben vannak.

3. A kölcsönhatás erőssége nő az $\mathrm{X}$ háttératom elektronegativitásával $(\mathrm{F}>\mathrm{O}>\mathrm{N}>\mathrm{C})$ és polározhatóságával $(\mathrm{S}>\mathrm{N} \sim \mathrm{C})$.

4. Az oxigén jóval közelebb van a kénhez, mint a van der Waals távolság.

5. A vonzó kölcsönhatást jellemző $\Delta \mathrm{r}(\mathrm{S} \cdots \mathrm{O})$ távolságcsökkenés mindig jelentős.

6. $\mathrm{Az} r(\mathrm{~S} \cdots \mathrm{O})$ távolságok csökkenésével az $\mathrm{r}(\mathrm{C}=\mathrm{O})$, $\mathrm{r}(\mathrm{N}=\mathrm{O})$ és $\mathrm{r}(\mathrm{X}-\mathrm{S})$ távolságok kismértékben növekednek.

7. Az s-transz $\rightarrow$ s-cisz konformációváltozás jelentős energiacsökkenéssel jár. Lineáris összefüggés áll fenn a kén-oxigén kölcsönhatásban lévő atomokra számított kötésrend és az s-transz $\rightarrow$ s-cisz átalakulásra számolt energiacsökkenés között.

8. A kén-oxigén kölcsönhatás részleges kovalens kötés kialakulásával és az atomok polaritásának növekedésével jár együtt.

Az eredmények alapján megállapítható volt, hogy a kén-oxigén kölcsönhatás és a gyenge hipervalens kötések között nincs elvi különbség. Mivel a hipervalens kötések és a kén-oxigén kölcsönhatások elektronszerkezet szempontjából különböznek a valódi kovalens kötésektől, jelölésükre a hipervalens kötésekre a szaggatott vonal (----), a kén-oxigén kölcsönhatásoknál a pontsor $(\cdots \cdots)$ lenne leginkább ajánlható.

A kénorganikus kémia területén végzett kutatásokról 126 , nemzetközi folyóiratokban megjelent tudományos dolgozatot publikáltunk, nemzetközi konferenciákon 18 tudományos előadást tartottunk. Az eredmények iránti érdeklődést a cikkekre kapott 1500 feletti idézetek száma jellemzi. A kénorganikus csoport munkájának elismeréséként 1975-ben akadémia díjat kapott. A díjban Kucsman Árpád, Kapovits István, Kálmán Alajos, Ruff Ferenc és Tanács Béla részesült. 1996-ban a csoport vezető kutatói, Kucsman Árpád, Kapovits István és Ruff Ferenc megosztott Széchenyi Díjat kaptak. Ezeken túlmenően Kucsman Árpád professzor még Zemplén Géza fődíjban és Bruckner Győző díjban is részesült és a Magyar Tudományos Akadémia Eötvös Koszorút adott számára, Rábai József pedig Zemplén Géza díjat kapott. 
A Kucsman professzor által vezetett kénorganikus kémiai kutatásokban tanítványként, munkatársként és együttmüködő partnerként a következők vettek részt. Ádám Tibor, Ángyán János, Argay Gyula, Balla Mária, Bencze Zsolt, Bihari Mária, Bonelle C., Chambers J.Q., Csámpai Antal, Csizmadia Imre, Csonka Gábor, Csonka István, Czakó Klára, Czugler Mátyás, Daudel R., Duffin B., Fischer János, Farkas Ödön, Forgács György, Fülöp Viktor, Gulyás József, Harmat Veronika, Hargittai István, Holósi Miklós, Huszthy Péter, Innes E.A., Jalsovszky István, Kajtár-Peredi Mária, Kálmán Alajos, Kapovits István, Koritsánszky Tibor, Kövesdi István, Kremmer Tibor, Kuti Miklós, Liao Chi-sheng, Mayer Zsuzsa, Mezey Pál, Loos M., Nagy Péter, Náray-Szabó Gábor, Nemes András, Ösapay Klára, Párkányi László, Poirier R.A., Rábai József, Radics Lajos, Rivail J.-L., Robb M.A., Ruff Ferenc, Sasvári Kálmán, Schultz György, Schuster I., Serke I., Sólyom Sándor, Szabó Dénes, Szabó Gábor, Szarvas Szilvia, Szendeffy Szilárd, Szepes László, Szirtes Tamás, Szókán Gyula, Tamás József, Tanács Béla, Theodorakopoulos G., Vajda János, Vajda Miklós, Varga Jenő, Vass Elemér, Vass Gábor.

\section{Köszönetnyílvánítás}

A szerzők köszönetüket fejezik ki Dr. Nemes Anikónak a kézirat végleges formájának kialakításáért.

\section{A kénorganikus csoport közleményei}

1. Kucsman Á.: Über den Bau optisch aktiver Schwefelverbindungen. Acta Chim. Sci. Hung., 3, 47-55 (1953).

2. Kucsman Á., Kapovits I., Balla M.: Über den Mechanismus der Sulfilimine-Bildung - I. Die Reaktion substituirter Methylarylsulfide und Diarylsulfide mit Chloramine-T. Tetrahedron, 18, 75-78 (1962). https://doi.org/10.1016/0040-4020(62)80026-X

3. Kucsman Á., Kapovits I., Tanács B.: Über den Mechanismus der Sulfilimine-Bildung - II. Die Reaktion von Thioethercarbonsäuren mit Chloramine-T. Tetrahedron, 18, 79-86 (1962). https://doi.org/10.1016/0040-4020(62)80027-1

4. Kucsman Á., Kapovits I.: Über die Herstellung von symmetrischen Thiodibenzoesäuren. Acta Chim. Sci. Hung., 34, 71-74 (1962).

5. Kucsman Á., Kremmer T.: Kettenverlängerung der Thioäthercarbonsäuren mit hilfe der Arndt-EisterReaktion. Acta Chim. Sci. Hung., 34, 75-78 (1962). https://doi.org/10.1016/0040-4020(62)80026-X

6. Kapovits I., Kucsman Á.: Über die Synthese des 1,4-Dibrom-butan- und des 1,5-Dibrom-pentan-2-carbonsäureäthylesters. Acta Chim. Sci. Hung., 34, 79-86 (1962).

7. Kucsman Á., Kapovits I., Tanács B., Nemes A.: Herstellung der Tetrahydrothiopyran-2- und -3-carbonsäure. Beitrag zur Synthese von Thioäthercarbonsäuren. Acta Chim. Sci. Hung., 34, 87-91 (1962).

8. Kucsman Á., Kapovits I.: Über die Raumstructur der Sulfilimine. Ann. Univ. Sci. Budapest, Rolando Eötvös nom., Sect. Chim. 6, 161-170 (1964).

9. Kucsman Á., Kapovits I., Ruff F.: On the infrared absorption of N-acyl sulphilimines. Acta Chim. Sci. Hung., 40, 75-77 (1964).

10. Kucsman Á., Ruff F., Kapovits I.: Bindungsystem der N-Acyl-sulfilimine - I. IR-spektroskopische Untersuchung der N-Sulfonyl-sulfilimine. Tetrahedron, 22, 1575-1585 (1966). https://doi.org/10.1016/0040-4020(66)80148-5
11. Kucsman Á., Ruff F., Kapovits I., Fischer J.G.: Bindungsystem der N-Acyl-sulfilimine - II. IR-spektroskopische Untersuchung der N-Dihalogenacetylsulfilimine. Tetrahedron, 22, 1843-1849 (1966). https://doi.org/10.1016/S0040-4020(01)82258-4

12. Kucsman Á., Ruff F., Kapovits I.: Bindungsystem der N-Acyl-sulphilimine - III. UV-spektroskopische Untersuchung der N-Acyl-sulfilimine. Acta Chim. Sci. Hung., 50, 325-337 (1966).

13. Vajda, M., Ruff, F.: The polarography of sulphilimines - I. The reduction of simple S,S-dialkyl-toluene-suphonylsulphilimines. In: Polarography 1964, Vol. 2. pp. 759-760. MacMillan, London. 1966.

14. Kálmán, A.: Crystal and molecular structure of S,S-dimethyl-N-methylsulphonylsulphilimine, $\left(\mathrm{CH}_{3}\right)_{2} \mathrm{SNSO}_{2} \mathrm{CH}_{3}$. Acta Crystallogr., 22, 501-507 (1967). https://doi.org/10.1107/S0365110X67001057

15. Kucsman Á., Kálmán, A. Kapovits I.: The bond system of $\mathrm{N}$-acyl sulfilimines - IV. The delocalized $\mathrm{S}^{\mathrm{IV}} \mathrm{NS}^{\mathrm{VI}} \mathrm{d} \pi$ bond system and conformation of N-sulfonyl sulfilimines. Acta Chim. Sci. Hung., 53, 97-104 (1967).

16. Kucsman Á., Kapovits I., Ruff F.: Bindungsystem der N-Acyl-sulphilimine - V. IR-spektroskopische Untersuchung der N-p-nitrophenylsulfonyl-sulfilimine. Acta Chim. Sci. Hung., 54, 153-160 (1967).

17. Kucsman Á., Ruff F., Sólyom., Szirtes, T.: Bindungsystem der N-Acyl-sulphilimine - VI. Konjugativer Effect der S-Methyl-N-p-tolyl-sulfonyl-sulfilimingruppe. Acta Chim. Sci. Hung., 57, 205-212 (1968).

18. Ruff F., Kucsman Á., Schuster, I., Kapovits I., Bindungsystem der N-Acyl-sulphilimine - VII NMR-spektroskopische Untersuchung der N-Acylsulfilimine. Acta Chim. Sci. Hung., 58, 85-91 (1968).

19. Ruff F., Kucsman Á.: Über den Mechanismus der Sulfilimine-Bildung - III. Kinetische Untersuchung der Reaktion einiger Methyl-aryl-sulfide mit Chloramin-T. Acta Chim. Sci. Hung., 62, 437-443 (1969).

20. Ruff F. Kucsman Á.: Über den Mechanismus der Sulfilimine-Bildung - IV. Kinetische Untersuchung der Reaktion einiger Methyl-aryl-sulfide mit Chloramin-T: pH-Abhängigkeit und Substituenteffect Acta Chim. Sci. Hung., 65, 107-113 (1970).

21. Tanács, B., Kucsman Á.: Bindungsystem der N-Acyl-sulphilimine - VIII. Herstellung von ${ }^{15} \mathrm{~N}$-Acylsulfiliminen. Acta Chim. Sci. Hung., 65, 369-373 (1970).

22. Mezey P.: The bond system of N-acyl sulfilimines $-\mathrm{X}$. $\pi$-electron structure of $\mathrm{N}$-dichloroacetyl sulfilimines. Acta Chim. Sci. Hung., 65, 389-395 (1970).

23. Kálmán, A., Duffin, B., Kucsman Á.: Crystal and molecular structure of S,S-diphenyl-N-p-tolylsulfonyl-sulfilimine. (The bond system of N-acylsulfilimnes - XI). Acta Crystallogr., Sect. B, 27, 586-594 (1971). 24.

Kapovits, I., Kálmán, A.: Formation and structure of a four-coordinate organosulfur(IV) compound. J. Chem. Soc. Chem. Commun., 649-651 (1971). https://doi.org/10.1107/S0567740871002607

24. Kapovits, I., Kálmán, A.: Formation and structure of a four-coordinate organosulfur(IV) compound. J. Chem. Soc. Chem. Commun., 649-651 (1971). https://doi.org/10.1039/C2971000649B

25. Kálmán, A., Sasvári, K., Kucsman Á.: Crystal and molecular structure of S,S-diethyl-N-dichloroacetyl sulphilimine. J. Chem. Soc. Chem. Commun., 1447-1448 (1971). https://doi.org/10.1039/C29710001447

26. Mezey, P. Kucsman, Á.: Rotation about a sulphur(IV)-nitrogen double bond. J. Chem. Soc. Chem. Commun., 1448-1449 (1971). https://doi.org/10.1039/C29710001448 
27. Kapovits, I., Ruff, F., Kucsman Á.: Acid catalysed hydrolysis of the S(IV)N bond in N-sulphonyl sulphilimines - I. Mechanism and substituent effect. Tetrahedron, 28, 4405-4412 (1972). https://doi.org/10.1016/S0040-4020(01)88963-8

28. Kapovits, I., Ruff, F., Kucsman Á.: Basicity of $\mathrm{S}(\mathrm{IV}) \mathrm{N}\left(\mathrm{sp}^{2}\right) \mathrm{S}(\mathrm{VI})$ group in N-sulphonyl sulphilimines. Tetrahedron, 28, 4413-4417 (1972). https://doi.org/10.1016/S0040-4020(01)88964-X

29. Mezey, P. Kucsman, Á.: Rotation-independent conjugation between a sulphur(IV)-nitrogen double bond and a sulphonyl group. J. Chem. Soc., Faraday Trans. 2, 68, 2060-2063 (1972). https://doi.org/10.1039/f29726802060

30. Kálmán, A., Sasvári, K.: S-Propyl-S-phenyl-N-tolylsulphonylsulphilimine, $\mathrm{C}_{16} \mathrm{H}_{19} \mathrm{NO}_{2} \mathrm{~S}_{2}$. Cryst. Struct, Commun., 1, 243-246 (1972).

31. Kálmán, A., Sasvári, K., Kapovits, I.: Structure of bis-(2-carboxyphenyl)sulphur-dihydroxy-dilactone. Acta Crystallogr., Sect. B, 29, 355-357 (1973). 32. Kálmán, A., Sasvári, K., Kucsman, Á.: The crystal and molecular stucture of S,S-dimethyl-N-trichloroacetyl sulphilimine, $\mathrm{C}_{4} \mathrm{H}_{6} \mathrm{ONSCl}_{3}$. Acta Crystallogr., Sect. B, 29, 1241-1244 (1973). https://doi.org/10.1107/S0567740873002475

32. Kálmán, A., Sasvári, K., Kucsman, Á.: The crystal and molecular stucture of S,S-dimethyl-N-trichloroacetyl sulphilimine, C4H6ONSCl3. Acta Crystallogr., Sect. B, 29, 1241-1244 (1973). https://doi.org/10.1107/S0567740873004310

33. Liao, Chi-Sheng, Chambers, J.Q., Kapovits, I., Rábai, J. Electrochemistry of four-co-ordinated quadrivalent organosulphur(IV) compounds. J. Chem. Soc. Chem. Commun., 149-150 (1974). https://doi.org/10.1039/c39740000149

34. Mezey, P., Kucsman, Á., Theodorakopoulos, G., Csizmadia, I.G.: Theoretical conformation analysis of a simple sulphilimine model. Theor. Chim. Acta. 38, 115-119 (1975). https://doi.org/10.1007/BF00581468

35. Ruff, F., Kucsman, Á.: Mechanism of the reaction of sulphides with N-chloroarenesulphonamides. J. Chem. Soc., Perkin Trans. 2, 509-519 (1975). https://doi.org/10.1039/p29750000509

36. Kucsman, Á., Ruff, F., Tanács, B.: IR spectroscopic studies of ${ }^{15} \mathrm{~N}$-acyl sulphilimines (The bond system of N-acyl sulphilimines - IX). Int. J. Sulfur Chem., 8, 505-510 (1974).

37. Kapovits, I., Ruff, F., Gulyás, J., Kucsman Á.: Acid-catalysed hydrolysis of N-sulphonyl sulphilimines - II. Tetrahedron, 32, 1811-1818 (1976). https://doi.org/10.1016/0040-4020(76)85179-4

38. Ruff, F., Komoto, K., Furukawa, N., Oae, S.: Steric effect in the reaction of alkyl-phenyl and diakyl-suphides with chloramine-T. Tetrahedron, 32, 2763-2767 (1976). https://doi.org/10.1016/0040-4020(76)80120-2

39. Theodorakopoulos, G., Csizmadia, I.G., Robb, M.A., Kucsman, Á., Kapovits, I.: Experimental (ESCA) and theoretical (SCF-MO) determination of the oxidation state of sulphur in bis-(2-carboxyphenyl) sulphur dihydroxi dilactone. J. Chem. Soc., Faraday Trans. 2, 73, 293-297 (1977). https://doi.org/10.1039/F29777300293

40. Ösapay. K., Mezey, P., Kucsman, Á.: Theoretical conformational analysis of sulphilimines of the S-aryl type. In: Progress in Theoretical Chemistry, Vol. 2. Application of MO Theory in Organic Chemistry, (I.G. Csizmadia), Amsterdam, Elsevier, 1977, pp. 34-46.

41. Kucsman, Á., Kapovits, I.: Structure, stereochemistry and mechanism of formation of sulfilimines. Phosphorus Sulfur, 3, 9-18 (1977). https://doi.org/10.1080/03086647708070724

42. Ruff, F., Kapovits, I., Rábai, J., Kucsman Á.: Neighbouring group participation in the reaction of sulphides with chloramine-T. Tetrahedron, 34, 2767-2773 (1978). https://doi.org/10.1016/0040-4020(78)88417-8
43. Huszthy, P., Kapovits, I., Kucsman Á., Radics, L.: Synthesis of optically active spirosulfuranes. Tetrahedron Letters, 1853-1856 (1978). https://doi.org/10.1016/S0040-4039(01)94689-1

44. Bihari, M., Tamás, J., Kapovits, I., Rábai, J.: Ortho-effect in the electron impact fragmentation of some diarylsulphides, -sulphoxides, and -sulphones. In: Advances in Mass Spectrometry, Vol. 7B. (Proceedings of the International Mass Spectrometry Conference, Firenze, 1976. N.R. Day, London.) 1978, 1362-1370.

45. Náray-Szabó, G., Kucsman, Á.: Localized molecular-orbital representation of the bonding in $\mathrm{N}$-sulphinosulphimides. J. Chem. Soc., Dalton Trans., 891-894 (1979). https://doi.org/10.1039/DT9790000891

46. Kapovits, I., Rábai, J., Ruff, F., Kucsman Á.: Diaryldiacyloxyspirosulfuranes - I. Synthesis from sulfides with halogenating agents. Tetrahedron, 35, 1869-1874 (1979). https://doi.org/10.1016/0040-4020(79)80012-5

47. Kapovits, I., Rábai, J., Ruff, F., Kucsman Á., Tanács, B.: Diaryldiacyloxyspirosulfuranes - II. Synthesis from sulfoxides and hydrolysis. Tetrahedron, 35, 1875-1881 (1979). https://doi.org/10.1016/0040-4020(79)80013-7

48. Schultz. G., Serke, I., Kapovits, I.: Molecular structure of o-phenylene sulphite, an electron diffraction study. J. Chem. Soc., Faraday Trans. 2. 75, 1612-1619 (1979). https://doi.org/10.1039/f29797501612

49. Ruff, F., Szabó, G., Vajda, J., Kövesdi, I., Kucsman Á.: Stereochemistry of sulphilimine and sulphoxide formations in reactions of sulphides with chlorinating agents and nucleophilies. Tetrahedron, 36, 1631-1641 (1980). https://doi.org/10.1016/S0040-4020(01)83133-1

50. Kálmán, A., Párkányi, L., Kucsman, Á.: A reinvestigation of the structure of S,S-dimethyl-N-methylsulphonylsulphilimine. Acta Crystallogr., Sect. B, 36, 1440-1443 (1980). https://doi.org/10.1107/S0567740880006231

51. Szókán, G., Ruff, F., Kucsman, Á.: High-performance liquid chromatography of diastereomeric sulphoxides and sulphilimines. J. Chromatogr. 198, 207-211 (1980). https://doi.org/10.1016/S0021-9673(00)80112-0

52. Theodorakopoulos, G., Kucsman, Á., Kapovits, I., Náray-Szabó, G., Csizmadia, I.G.: Minimal basis study of inner shell ionization potentials for molecules containing sulphur: S,S-diphenyl-N-p-tolylsulphonyl-sulphilimine. J. Computation. Chem. 2, 212-217 (1981). https://doi.org/10.1002/jcc.540020212

53. Kövesdi, I.: A new static NMR method for the determination of magnetic susceptibilities. J. Magn. Res. 43, 1-7 (1981). https://doi.org/10.1016/0022-2364(81)90074-3

54. Kálmán, A., Koritsánszky, T., Kapovits, I., Kucsman, Á.: A reinvestigation of the structure of N-dichloracetyl-S,Sethylsulphilimine. Acta Crystallogr., Sect. B, 38, 1843-1845 (1982). https://doi.org/10.1107/S0567740882007390

55. Ruff, F., Kucsman, Á.: Mechanism of the reaction of dialkyl sulphides with bromamine T in alkaline medium. J. Chem. Soc., Perkin Trans. 2, 1075-1079 (1982). https://doi.org/10.1039/p29820001075

56. Schultz. G., Hargittai, I., Kapovits, I., Kucsman, Á.: Molecular structure of 2-nitrobenzenesuphenyl chloride. An electron-diffraction study. J. Chem. Soc., Faraday Trans. 2. 80, 1273-1279 (1984). https://doi.org/10.1039/f29848001273

57. Kucsman, Á., Kapovits, I., Párkányi, L., Argay, Gy., Kálmán, A.: Intramolecular sulphur(II)-oxygen interaction in sulphides and disulphides with 2-methoxycarbonylphenyl and 2-nitrophenyl groups: an X-ray study. J. Mol. Struct., 125, 331-347 (1984). https://doi.org/10.1016/0022-2860(84)85031-0

58. Kucsman, Á., Kapovits, I., Kövesdi, I., Kálmán, A., Párkányi, L.: Intramolecular sulphur(IV)-oxygen interaction in sulphoxides and sulphilimines with 2-methoxycarbonylphenyl and 2-nitrophenyl groups: an X-ray study. J. Mol. Struct., 127, 135-148 (1985). https://doi.org/10.1016/0022-2860(85)80158-7 
59. Ruff, F., Kucsman, Á.: Mechanism of the oxidation of sulphides with sodium periodate. J. Chem. Soc., Perkin Trans. 2, 683-687 (1985).

https://doi.org/10.1039/p29850000683

60. Ángyán, J., Kucsman, Á., Poirier, R.A., Csizmadia, I.G.: Intramolecular sulphur-oxigen interaction: an ab initio conformational study of (Z)-3-fluorothio-2-propenal. J. Mol. Struct., 123, 189-201 (1985). https://doi.org/10.1016/0166-1280(85)80163-9

61. Kucsman, Á., Kapovits, I.: Nonbonded sulfur-oxygen interaction in organic sulfur compounds. In: Organic Sulfur Chemistry: Theoretical and Experimental Advances (F. Bernardi, I.G. Csizmadia, A. Mangini), Amsterdam, Elsevier, 1985, Ch.4, pp. 191-245. https://doi.org/10.1002/chin.198552342

62. Kucsman, Á., Kapovits, I., Párkányi, L., Kálmán, A.: Conformation of diaryl sulphides with intramolecular sulphur(II)-oxygen interaction: an X-ray study of methyl 2-(4-nitrophenylthio)-benzoate and 2-diazoacetyl-4'nitrodiphenyl sulphides. J. Mol. Struct., 140, 141-150 (1986). https://doi.org/10.1016/0022-2860(86)80156-9

63. Jalsovszky, I., Ruff, F., Kajtár-Peredy, M., Kövesdi, I., Kucsman, Á.: Stereoselective synthesis of cis and trans N-tosyl sulphilimines and sulphoxides from 2-alkylthianes and 2-alkylthiolanes. Assignements of configurations and preferred conformations. Tetrahedron, 42, 5649-5656 (1986). https://doi.org/10.1016/S0040-4020(01)88170-9

64. Jalsovszky, I., Szókán, Gy., Ruff, F., Kucsman, Á.: High-performance liquid chromatography of cyclic sulphilimine and sulphoxide diastereoisomers. J. Chromatogr. 389, 439-443 (1987). https://doi.org/10.1016/S0021-9673(01)94456-5

65. Jalsovszky, I., Kucsman, Á., Ruff, F., Koritsánszky, T., Argay, Gy., Kálmán, A.: Conformatinal analysis of thiane-1-imides: an X-ray study of thiane-1-tosylimide and diastereoisomeric 2-alkyl- and 4-phenylthiane-1tosylimides. J. Mol. Struct., 156, 165-192 (1987). https://doi.org/10.1016/0022-2860(87)87023-0

66. Jalsovszky, I., Kucsman, Á., Ruff, F., Argay, Gy., Koritsánszky, T., Kálmán, A.: Conformatinal analysis of thiolane-1-imides: an X-ray study of thiolane-1-tosylimide and diastereoisomeric 2-alkylthiolane-1-(arylsulphonyl)imides. J. Mol. Struct., 156, 193-212 (1987). https://doi.org/10.1016/0022-2860(87)87024-2

67. Ángyán, J., Poirier, R.A., Kucsman, A., Csizmadia, I.G.: Bonding between nonbonded sulfur oxygen atoms in selected organic molecules. (A quantum chemical study). J. Amer. Chem. Soc., 109, 2237-2245 (1987). https://doi.org/10.1021/ja00242a001

68. Ángyán, J., Daudel, R., Kucsman, Á., Csizmadia, I.G.: Surface modification by substitution, changing topology of conformational potential energy surfaces. Chem. Phys. Letters, 136, 1-8 (1987). https://doi.org/10.1016/0009-2614(87)87287-1

69. Schultz. Gy., Hargittai, I., Kapovits, I., Kucsman, Á.: Molecular structure of methyl-2-nitrophenyl sulphide. An electron-diffraction study. J. Chem. Soc., Faraday Trans. 2. 83, 2113-2123 (1987). https://doi.org/10.1039/f29878302113

70. Ruff, F., Kucsman, Á.: Electronic effect, steric hindrance and anchimeric assistance in the oxidation of sulphides. Neighbouring-group participation through sulphur-oxigen non-bonded interaction. J. Chem. Soc., Perkin Trans. 2, 1123-1128 (1988). https://doi.org/10.1039/P29880001123

71. Ángyán, J., Bonelle, C., Daudel, R., Kucsman, Á., Csizmadia, I.G.: The use of theoretical indices for the characterization of S-O linkage multiplicity. J. Mol. Struct., Theochem, 165, 273-287 (1988).

https://doi.org/10.1016/0166-1280(88)87025-8
72. Schultz, Gy., Kucsman, Á., Hargittai, I.: The molecular structure of thiane from electron diffraction. Acta Chem. Scand., A 42, 332-337 (1988).

https://doi.org/10.3891/acta.chem.scand.42a-0332

73. Ángyán, J., Daudel, R., Kucsman, Á., Csizmadia, I.G.: Intramolecular sulfur-oxigen interactionin sulfonium compounds and sulfoxides. J. Mol. Struct., Theochem, 186, 53-60 (1989). https://doi.org/10.1016/0166-1280(89)87038-1

74. Forgács, Gy., Schultz. Gy., Hargittai, I., Jalsovszky, I., Kucsman, Á.: Molecular structure of tetrahydrothiophene1-oxide and cis-2-methyltetrahydro- thiophene-1-oxide from electron-diffraction. J. Chem. Soc., Faraday Trans. 2. 85, 303-315 (1989). https://doi.org/10.1039/F29898500303

75. Kucsman, Á., Kapovits, I., Czugler, M., Párkányi, L., Kálmán, A.: Intramolecular sulphur-oxygen interaction in organosulphur compounds with different sulphur valence state: an X-ray study of methyl 2-nitrobenzenesulphenate, -sulphinate, -sulphonate and 2-nitrobenzenesuphenyl chloride. J. Mol. Struct., 198, 339-353 (1989). https://doi.org/10.1016/0022-2860(89)80048-1

76. Párkányi, L., Kálmán, A., Kucsman, Á., Kapovits, I.: Intramolecular sulphur(II)-oxygen interaction in acyl chlorides: an X-ray study of 2,2'-thiodibenzoyl chloride and 2,2'-dithiodibenzoyl chloride. J. Mol. Struct., 198, 355-364 (1989). https://doi.org/10.1016/0022-2860(89)80049-3

77. Rábai, J.: 3-Mercaptopropionic Acid: A new tool in the synthesis of symmetrical diaryl sulfides from unactivated aryl iodides as substitute for anhydrous sodium sulfide. Synthesis, 523-525 (1989). https://doi.org/10.1055/s-1989-27305

78. Bencze, Zs., Kucsman, Á., Schultz, Gy., Hargittai, I.: The molecular structure of 1,3,5-trithiane from electron diffraction. Acta Chem. Scand., 43, 953-956 (1989). https://doi.org/10.3891/acta.chem.scand.43-0953

79. Szabó, D., Kapovits, I., Kucsman, Á., Fülöp, V., Czugler, M., Kálmán, A.: Cyclic Sulfonium salts with S-O interactions -1 . Molecular structures with five-membered rings. Struct. Chem., 1, 305-308 (1990). https://doi.org/10.1007/BF00674275

80. Ruff, F., Kucsman, Á.: Neighbouring-group participation in the oxidation of sulphides with hydrogen peroxide. Gazz. Chim. Ital., 120, 241-246 (1990). https://doi.org/10.1002/chin.199042098

81. Rábai, J., Kapovits, I., Tanács, B., Tamás, J.: Phenyltrimethylammonium tribromide for selective oxidation of sulfides to sulfoxides. A convenient synthesis of sulfinyl ${ }^{18}$ O-labelled sulfoxide carboxylic acids. Synthesis, 847-849 (1990). https://doi.org/10.1055/s-1990-27033

82. Jalsovszky, I., Ruff, F., Kajtár-Peredy, M., Kucsman, Á.: Stereoselective synthesis of trans-2-alkylthiane-1-oxide. Synthesis, 1037-1039 (1990). https://doi.org/10.1055/s-1990-27088

83. Forgács, Gy., Hargittai, I., Jalsovszky, I., Kucsman, Á.: The molecular structure of tiane-1-oxide from electron diffraction. J. Mol. Struct., 243, 123-130 (1991). https://doi.org/10.1016/0022-2860(91)87030-L

84. Loos, M., Rivail, J.-L., Kucsman, Á., Csizmadia, I.G.: Conformationally induced double degenerate uneven sulfuranes. J. Mol. Struct., Theochem, 230, 143-153 (1991). https://doi.org/10.1016/0166-1280(91)85176-8

85. Szabó, D., Kapovits, I.: Syntheses of some spirosulfurane precursor sulfides. Sulfur Letters, 13, 37-44 (1991).

86. Szabó, D., Kapovits, I., Kucsman, Á., Czugler, M., Fülöp, V., Kálmán, A.: Cyclic Sulfonium salts with S-O interactions -2 . Molecular structures with six-membered rings. Struct. Chem., 2, 529-535 (1991). https://doi.org/10.1007/BF00672886 
87. Szabó, D., Kapovits, I., Kucsman, Á., Czugler, M., Argay, Gy., Kálmán, A.: Hydrogen-bonded molecular complexes of cyclic carboxyaryl sulfonium salts with chlorides: Synthesis and molecular structures. J. Chem. Soc., Chem. Commun., 571-573 (1992). https://doi.org/10.1039/C39920000571

88. Rábai, J.: Salting out selective extraction. A novel method for the optical resolution of chiral sulfinylcarboxilic acids and its application for convenient determination of opurity. Angew. Chem. Int. Ed. Engl., 31, 1631-1633 (1992). https://doi.org/10.1002/anie.199216311

89. Kapovits, I., Rábai, J., Szabó, D., Czakó, K., Kucsman, Á., Argay Gy., Fülöp, V., Kálmán, A., Koritsánszky, T., Párkányi, L.: Diaryldiacyloxyspirosulfuranes. Part 3. Sulfuranes with five-, six- and seven-membered spirorings: Syntheses and molecular structures. J. Chem. Soc., Perkin Trans. 2, 847-853 (1993). https://doi.org/10.1039/P29930000847

90. Vass, E., Ruff, F., Kapovits, I., Rábai, J., Szabó, D.: Diaryldiacyloxyspirosulfuranes. Part 4. A kinetic study on the mechanism of hydrolysis. J. Chem. Soc., Perkin Trans. 2, 855-859 (1993). https://doi.org/10.1039/P29930000855

91. Szabó, D., Kapovits, I., Kucsman, Á., Huszthy, P., Argay, Gy., Czugler, M., Fülöp, V., Kálmán, A., Koritsánszky, T., Párkányi, L.: Spirosufuranes with different heteroatoms in axial positions. A comparison of $\mathrm{N}-\mathrm{S}(\mathrm{IV})-\mathrm{O}$ and $\mathrm{N}-\mathrm{S}^{+}(\mathrm{IV}) \cdot \bullet \mathrm{O}=$ bond systems. J. Mol. Struct., 300, 23-46 (1993). https://doi.org/10.1016/0022-2860(93)87004-S

92. Jalsovszky, I., Ruff, F., Kucsman, Á.: Stereoelectronic effect in equilibration and methoxy exchange of cyclic methoxysulfonium sats. Tetrahedron, 49, 8407-8417 (1993). https://doi.org/10.1016/S0040-4020(01)81923-2

93. Kuti, M., Rábai, J., Kapovits, I.: Novel reactions of spirosulfurane precursor sulfides and sulfoxides. Phosphorus, Sulfur and Silicon, 85, 119-127 (1993). https://doi.org/10.1080/10426509308038190

94. Loos, M., Rivail, J.-L., Kucsman, Á., Csizmadia, I.G.: Constitutionally symmetric, structurally uneven sulfuranes. Phosphorus, Sulfur and Silicon, 85, 441-442 (1993). https://doi.org/10.1080/10426509308038154

95. Kálmán, A., Párkányi, L., Szabó, D.: The structure of a spirosulfurane rearrangement product: X-ray study of a ten-membered cyclic acid anhydride. J. Mol. Struct., 317, 279-285 (1994). https://doi.org/10.1016/0022-2860(93)07888-4

96. Kuti, M., Rábai, J., Kapovits, I., Kucsman, Á., Párkányi. L., Argay Gy., Kálmán, A.: Transannular sulfur-nitrogen interaction in 1,5-thiazonine derivatives: an X-ray study. J. Mol. Struct., 318, 161-169 (1994). https://doi.org/10.1016/0022-2860(93)07890-9

97. Kuti, M., Rábai, J., Kapovits, I., Kucsman, Á., Párkányi. L., Argay Gy., Kálmán, A.: Conversion of diaryl sulfoxides to cyclic sulfonium ylide: Dehydration with sigma-bond shift and decarboxylation. ACH-Models in Chemistry, 131, 313-325 (1994).

98. Innes, E.A., Csizmadia, I.G., Rivail, J.-L., Loos, M., Kucsman, Á.: Conformationally induced and conjugatively amplified doubly degenerate uneven sulfuranes. Can. J. Chem., 72, 2153-2158 (1994). https://doi.org/10.1139/v94-273

99. Csonka, G.I., Loos, M., Kucsman, Á., Csizmadia, I.G.: Ab initio geometry optimization of the $\mathrm{Cl}-\mathrm{S}(\mathrm{H}) \mathrm{OH}-\mathrm{Cl}$ uneven sulfurane with the inclusion of electron correlation. J. Mol. Struct., Theochem, 315, 29-33 (1994). https://doi.org/10.1016/0166-1280(94)03759-E

100. Csonka, G.I., Loos, M., Kucsman, Á., Csizmadia, I.G.: Ab initio study of the energy hypersurface of uneven sulfuranes. Dissociation of $\mathrm{HCl}$ from Cl-SH(OH)-Cl. Chem. Phys. Letters, 230, 203-208 (1994). https://doi.org/10.1016/0009-2614(94)01155-9

101. Rábai, J., Kapovits, I., Argay Gy., Koritsánszky, T., Kálmán, A.: Diaryl(acyloxy)sulfonylaminospiro- $\lambda^{4}$ sulfanes. Synthesis, molecular structure and rearrangement. J. Chem. Soc., Chem. Commun., 1069-1070 (1995). https://doi.org/10.1039/C39950001069
102. Jalsovszky, I., Farkas, Ö., Rábai, J., Kucsman, Á.: The extent of transannular sulfur-nitrogen interaction in stereoisomeric 1,5-thiazocine derivatives: A semiempirical MO study. J. Mol. Struct., Theochem, 365, 93-102 (1996). https://doi.org/10.1016/0166-1280(96)04482-X

103. Kuti, M., Rábai, J., Kapovits, I., Jalsovszky, I., Argay, Gy., Párkányi. L.: Transannular sulfir-nitrogen interaction in thiazocine derivatives: an X-ray study. J. Mol. Struct. 382, 1-11 (1996). https://doi.org/10.1016/0022-2860(96)09237-X

104. Rábai, J., Kapovits, I., Jalsovszky, I., Argay, Gy., Fülöp, V., Kálmán, A., Koritsánszky, T.: Molecular structure of cyclic sulfilimines without and with intramolecular sulfur-oxigen interaction: an X-ray study. J. Mol. Struct. 382, 13-21 (1996). https://doi.org/10.1016/0022-2860(96)09248-4

105. Szabó, D., Kapovits, I., Argay, Gy., Czugler, M., Kálmán, A., Koritsánszky, T.: Spiro- $\lambda^{4}$-sulfanes with O-ligands of different electronegativity in axial positions. A comparison of $\mathrm{CH}_{2} \mathrm{O}-\mathrm{S}(\mathrm{IV})-\mathrm{OCO}$ and $\mathrm{CH}_{2} \mathrm{O}-\mathrm{S}^{+}(\mathrm{IV}) \cdot \cdots \mathrm{O}=\mathrm{C}$ bond systems. J. Chem. Soc., Perkin Trans. 2. 1045-1053 (1997). https://doi.org/10.1039/a604157d

106. Jalsovszky, I., Farkas, Ö., Kucsman, Á.: Transannular sulfur-nitrogen interactions in stereoisomeric 1,5-thiazocine derivatives: An ab initio MO study. J. Mol. Struct., Theochem, 418, 155-163 (1997). https://doi.org/10.1016/S0166-1280(97)00170-X

107. Szabó, D., Kuti, M., Kapovits, I., Rábai, J., Kucsman, Á., Argay, Gy., Czugler, M., Kálmán, A., Párkányi, L.: Spiro- $\lambda^{4}$-sulfanes with intramolecular sulfur-oxigen interactions: synthesis and molecular structures. J. Mol. Struct. 415, 1-16 (1997). https://doi.org/10.1016/S0022-2860(97)00098-7

108. Vass, E., Ruff, F., Kapovits, I., Szabó, D., Kucsman, Á.: Spiro- $\lambda^{4}$-sulfanes with N-S(IV)-O axial bond system. A kinetic study on the mechanism of hydrolysis. J. Chem. Soc., Perkin Trans. 2. 2061-2068 (1997). https://doi.org/10.1039/a701002h

109. Szabó, D., Szendeffy, Sz., Kapovits, I., Kucsman, Á., Argay, Gy., Kálmán, A., Párkányi, L.: Resolution and absolute configuration of enantiomeric spiro- $\lambda^{4}$-sulfaneprecursor diaryl sulfoxides. Tetrahedron: Asymmetry, 8, 2403-2410 (1997). https://doi.org/10.1016/S0957-4166(97)00244-9

110. Szabó, D., Szendeffy, Sz., Kapovits, I., Kucsman, Á., Czugler, M., Kálmán, A., Nagy, P.: Stereospecific synthesis and absolute configuration of optically active diaryl(acyloxy)(alkoxy)spiro- $\lambda^{4}$-sulfanes. Tetrahedron: Asymmetry, 8, 2411-24 20 (1997). https://doi.org/10.1016/S0957-4166(97)00245-0

111. Kapovits, I., Rábai, J., Szabó, D., Kuti, M.: Rearrangements in spiro- $\lambda^{4}$-sulfane chemistry. Phosphorus, Sulfur and Silicon, 120-121, 435-436 (1997). https://doi.org/10.1080/10426509708545585

112. Szabó, D., Ádám, T., Kapovits, I.: Syntheses of cyclic diaryl(acylamino)sulfonium salts and diarylbis(acylamino)spiro$\lambda^{4}$-sulfanes. Sulfur Letters, 21, 21-34 (1997).

113. Ádám, T., Ruff, F., Kapovits, I., Szabó, D., Kucsman, Á.: Diarylbis(acylamino)spiro- $\lambda^{4}$-sulfanes and cyclic acylaminosulfonium salts: A kinetic study of equilibrium and hydrolysis reactions. J. Chem. Soc., Perkin Trans. 2, 1269-1275 (1998). https://doi.org/10.1039/a705660e

114. Szendeffy, Sz., Szarvas, Sz., Szabó, D., Kapovits, I., Hollósi, M.: Chiroptical properties of diaryl-spiro- $\lambda^{4}$-sulfanes: An exciton chirality model. Enantiomer, 3, 323-329 (1998).

115. Csonka, I.P., Vass, G., Szepes, L., Szabó, D., Kapovits, I.: $\mathrm{He}(\mathrm{I}) / \mathrm{He}(\mathrm{II})$ ultraviolet photoelectron spectroscopic studies on organosulfur compounds with emphasis on the sulfur-oxygen interaction. J. Mol. Struct. 455, 141-159 (1998). https://doi.org/10.1016/S0166-1280(98)00119-5 
116. Szókán, Gy., Szarvas, Sz., Mayer, Zs., Hollósi, M., Szabó, D., Kapovits, I.: On-line CD detection in chiral separation of spiro- $\lambda^{4}$-sulfanes. J. Liq. Chrom. \& Rel. Technol. 22, 993-1007 (1999). https://doi.org/10.1081/JLC-100101713

117. Szabó, D., Kapovits, I., Kucsman, Á., Nagy, P., Argay, Gy., Kálmán, A.: Hypervalent $\mathrm{S}-\mathrm{Cl}$ bonding cyclic acylaminochloro- $\lambda^{4}$-sulfanes: a comparison of $\mathrm{N}-\mathrm{S}-\mathrm{Cl}$, $\mathrm{N}-\mathrm{S}^{+} \mathrm{ClO}_{4}^{-}$and $\mathrm{N}-\mathrm{S}^{+} \cdot \cdots \mathrm{O}=\mathrm{C}$ bond system. J. Mol. Struct. 476, 157-171 (1999). https://doi.org/10.1016/S0022-2860(98)00543-2

118. Szabó, D., Varga, J., Csámpai, A., Kapovits, I.: Optically active cyclic diaryl(alkoxy)sulfonium salts with intramolecular $\mathrm{S} \bullet \cdot \mathrm{O}$ interaction: synthesis, absolute configuration and stereoselective hydrolysis. Tetrahedron: Asymmetry, 11, 1303-1312 (2000). https://doi.org/10.1016/S0957-4166(00)00064-1

119. Varga, J., Szabó, D., Hollósi, M.: Exciton coupling in the CD spectra of chiral spiro- $\lambda^{4}$-sulfanes and related sulfonium salts. Enantiomer, 5, 513-520 (2000).

120. Nagy, P., Csámpai, A., Szabó, D., Varga, J., Harmat, V., Ruff, F., Kucsman, Á.: Structure and mechanism of hydrolysis of diaryl(acylamino)(chloro)- $\lambda^{4}$-sulfanes and diaryl(acylamino)sulfonium salts. J. Chem. Soc., Perkin Trans. 2. 339-349 (2001). https://doi.org/10.1039/b008156f

121. Varga, J., Szabó, D., Sár, P.C., Kapovits, I.: Stereospecific synthesis and hydrolysis of optically active diaryl(acylamino)(acyloxy)spiro- $\lambda^{4}$-sulfanes and related cyclic diaryl(acylaminosulfonium salts. Tetrahedron: Asymmetry, 12, 745-753 (2001). https://doi.org/10.1016/S0957-4166(01)00113-6

122. Szabó, D., Ruff, F., Kucsman, Á.: 1,2-Oxathiole, 1,2-oxathiin, 1,2-thiazole and 1,2-thiazine derivatives with hypervalent bonds and close contacts. Targets in Heterocyclic Systems, Vol. V. 199-233 (2001).

123. Nagy, P., Szabó, D., Kapovits, I., Kucsman, Á., Argay, Gy., Kálmán, A.: Intramolecular $\mathrm{S} \bullet \cdot \mathrm{S}$ and $\mathrm{S} \cdots \cdot \mathrm{O}$ close contacts in 1,8-bis(phenylsulfanyl)naphthalene derivatives of different sulfur valence state: an X-ray study. J. Mol. Struct. 606, 61-76 (2002). https://doi.org/10.1016/S0022-2860(01)00821-3
124. Varga, J., Rábai, J., Ruff, F., Kucsman, Á., Vass, E., Hollósi, M., Szabó, D.: Synthesis and hydrolysis of optically active naphtyl-phenyl bis(acyloxy)spiro$\lambda^{4}$-sulfanes: absolute configurations of spiro- $\lambda^{4}$-sulfanes, related sulfonium salts and naphthyl phenyl sulfoxides determined by CD spectroscopy using exciton chirality and empirical rules. Tetrahedron: Asymmetry, 14, 3745-3753 (2003). https://doi.org/10.1016/j.tetasy.2003.09.011

125. Ruff, F., Fábián, A., Farkas, Ö., Kucsman, Á.: Mechanism for the Oxidation Sulfides and Sulfoxides with Periodates: Reactivity of the Oxidizing Species. Eur. J. Org. Chem. 2009, 2102-2111. https://doi.org/10.1002/ejoc.200801180

126. Ruff, F., Jalsovszky, I., Szabó, D., Rábai, J., Kucsman, Á.: Mechanism for the reactions of sulfides and sulfoxides with hypochlorites: racemization and oxygen exchange of oxysulfonium salts and sulfoxides. J. Phys. Org. Chem. 25, 1086-1096 (2012). https://doi.org/10.1002/poc.2941

\section{A közleményben idézett további cikkek.}

127. Martin, J.C., Arhart, J.J.: J. Am. Chem. Soc., 1971, 93, 2339. https://doi.org/10.1021/ja00738a053

128. Hayes, R.A., Martin, J.C.: In Organic Sulfur Chemistry: Theoretical and Experimental Advances; Elsevier: Amsterdam 1985, Ch. 4. 408-483.

129. Martin, J.C., Balthazor, T.M.: J. Am. Chem. Soc., 1977, 99 , 152. https://doi.org/10.1021/ja00443a029

130. Allenmark, S., Claeson, S.: Tetrahedron: Asymmetry, 1996, 4, 2329; https://doi.org/10.1016/S0957-4166(00)80095-6 Allenmark, S., Claeson, Enantiomers, 1996, 1, 423. https://doi.org/10.1016/S0165-7836(96)00503-6

131. Mayer, I.: Chem. Phys. Lett., 1984, 110, 440.; https://doi.org/10.1016/0009-2614(84)85461-5 Int. J. Quantum Chem., 1984, 26, 151. https://doi.org/10.1002/qua.560260111

\section{Studies on Sulfur Chemistry in the Institute of Organic Chemistry, Eötvös Loránd University, with the leadership of Professor Árpád Kucsman: 1953-2012}

Árpád Kucsman (born in 1927) got his master (1949) and PhD degree (1959) on the Eötvös Loránd University, became full professor of chemistry (1972), and was leader of the Institute of Organic Chemistry from 1972 till 1993. After his retire (1997) he continued his work with undiminished energy on organic sulfur chemistry problems till his death (2012).

Investigations of the research group on sulfur chemistry comprise the syntheses, the determination of the structure and bond system, and the study of the mechanism of formation and transformation of a large scale of sulfur compounds. To achieve the results the suitable methods of spectroscopy, X-ray and electron diffraction, chromatography, MO calculations were applied and the principles of stereochemistry, theoretical organic chemistry, reaction kinetics and quantum chemistry were used. The topics of the chapters are listed as follows.

1. Structure of sulfilimines, character of the sulfur-nitrogen bond (UV, IR, NMR, X-ray studies, MO calculations).

2. Mechanism of the formation of sulfilimines and sulfoxides from sulfides and N-halogen agents, neighboring group participation of the carboxyl group (kinetic studies, HPLC analysis, polarography, asymmetric induction).
3. Stereoselectiv syntheses and structure of cyclic sulfilimines and sulfoxides (HPLC analysis, X-ray studies, asymmetric induction).

4. Nucleophilic substitution on sulfonium center, acid catalyzed hydrolysis of sulfilimines (kinetic studies, polarography, principles of reactions in strong acids).

5. Mechanism of oxidation of sulfides to sulfoxides (kinetic studies, neighboring group participation, MO calculations).

6. Trigonal bipyramidal structure of $\lambda^{4}$-sulfanes.

7. Syntheses of stable and optically active spiro- $\lambda^{4}$-sulfanes and sulfonium salts with five and six member rings.

8. Structure of spiro- $\lambda^{4}$-sulfanes and analogous sulfonium salts (X-ray and CD studies).

9. Mechanism of hydrolyses of spiro- $\lambda^{4}$-sulfanes and analogous sulfonium salts (kinetic studies).

10. Sulfur-oxygen interaction (X-ray studies, electron diffraction, MO calculations).

The team of Professor Árpád Kucsman published 126 scientific papers and had several oral presentations and posters on international meetings. 